\title{
"Make Them Pay": Charting the Social Topography of an Old Assyrian Caravan Cycle
}

\author{
Edward P. Stratford \\ Brigham Young University - Provo, edstratford@gmail.com
}

Follow this and additional works at: https://scholarsarchive.byu.edu/facpub

Part of the History Commons

\section{Original Publication Citation}

Edward Stratford. Make Them Pay: Charting the Social Topography of and Old Assyrian Caravan Cycle. Journal of Cuneiform Studies Vol. 66 (2014), pp. 11-38. DOI: 10.5615/

jcunestud.66.2014.0011.

\section{BYU ScholarsArchive Citation}

Stratford, Edward P., "'Make Them Pay": Charting the Social Topography of an Old Assyrian Caravan Cycle" (2014). Faculty Publications. 1589.

https://scholarsarchive.byu.edu/facpub/1589

This Peer-Reviewed Article is brought to you for free and open access by BYU ScholarsArchive. It has been accepted for inclusion in Faculty Publications by an authorized administrator of BYU ScholarsArchive. For more information, please contact ellen_amatangelo@byu.edu. 


\title{
"MAKE THEM PAY": CHARTING THE SOCIAL TOPOGRAPHY OF AN OLD ASSYRIAN CARAVAN CYCLE
}

\author{
Edward Stratford (Brigham Young University)
}

With one foot on the Tigris and the other on the Anatolian plateau, Assyrian merchants conducted a brisk trade in tin, textiles, and silver in the late twentieth and early nineteenth centuries BCE. ${ }^{1}$ The structural aspects of the shipment and sale of tin and textiles in exchange for silver in caravan cycles have been the subjects of many excellent studies with methodologies including lexical studies and text-type studies. ${ }^{2}$ In addition, archival studies have been helpful in giving a sense of the variety of organization and involvement in the trade among different individuals. ${ }^{3}$ However, approaches that focus on structural activities like transporting, or on archives spanning a generation of activity, inevitably sublimate the context of merchants' short-term interests-interests that drove the creation and retention of the surviving documents. This is particularly so with the richest group of documents from the Old Assyrian trade, namely, the business letters sent between coordinating merchants scattered throughout the locales of the trade. Like most cuneiform missives, the Old Assyrian letters were not explicitly dated and few contain references that permit them to be secured confidently in the chronology of a merchant's life or in relation to other letters. As a result, many letters must often be read for structural patterns of the trade or as anecdotes, connecting most directly to recognizable contours of the human condition. Some correspondence can be recognized as pieces of a particular epistolary conversation. Such conversations are most easily recognized when the circumstances are

1. This article represents a revised section of my dissertation and of a paper read at the 220th Meeting of the American Oriental Society Conference, (St. Louis, Missouri), 12 March 2010. I would like to thank Mogens Trolle Larsen, Martha Roth, Seth Richardson, Gojko Barjamovic, and Thomas Hertel for their comments and criticism during the preparation of those earlier works. I also thank my reviewers for their helpful suggestions. Of course, I bear responsibility for any errors that persist. Abbreviations are cited according to the Chicago Assyrian Dictionary except for: Adana $=$ tablets in the collection of Adana Archaeological Muesum; AKT $=$ Ankara Kültepe Tabletleri; KEL $=$ Kültepe Eponym List; kt a/k, kt b/k ... kt 94/k = tablets from the excavations at Kültepe; LAPO = Littératures du Proche-Orient ancien; OAA/S = Old Assyrian Archives/Studies; $\mathrm{OBO}=$ Orbis Biblicus et Orientalis; PIHANS = Publications de l'Institut historique-archéologique neérlandais de Stamboul; POAT = Pennsylvania Old Assyrian Texts; TC = Tablettes cappadociennes $(T C L 4=$ TC 1; TCL 14 = TC 2; TCL 19-21 = TC 3); TPAK $=$ Tablettes paléo-assyriennes de Kültepe $;$ TTC $=$ Trente tablettes cappadociennes; VS = Vorderasiatische Schriftdenkmäler; WAG = tablets in the collection of the Walters Art Gallery in Baltimore.

2. M. T. Larsen, Old Assyrian Caravan Procedures, PIHANS 22 (Istanbul: Nederlands Historisch-Archaeologisch Instituut in het Nabije Oosten, 1967) and K. R. Veenhof, Aspects of Old Assyrian Trade and Its Terminology, Studia et Documenta 10 (Leiden: Brill, 1972). K. R. Veenhof and J. Eidem, Mesopotamia: The Old Assyrian Period, OBO 160/5 (Fribourg: Academic Press; Göttingen: Vandenhoeck \& Ruprecht, 2008) represents the most up-to-date survey of the field.

3. C. Michel, Innaya dans les tablettes paleo-assyriennes (Paris: Editions Recherche sur les Civilisations, 1991) marked a trend in focus on individuals and archives, continued by M. T. Larsen, The Aššur-nādā Archive, OAA 1/PIHANS 96 (Leiden: Nederlands Instituut voor het Nabije Oosten, 2002). The publication of the archaeologically recovered archives has made significant progress in the last one and one-half decades. C. Michel and P. Garelli, Tablettes paléo-assyriennes de Kültepe vol. 1: (Kt 90/k) (Paris: De Boccard, 1997) is now joined by the recent additions of I. Albayrak, Kültepe Tabletleri 4 (Istanbul: Türk Tarih Kurumu, 2006); K. R. Veenhof, The Archive of Kuliya, AKT 5 (Istanbul: Türk Tarih Kurumu, 2009); M. T. Larsen, The Archive of the Šalim-Aššur Family, vol. 1: The First Two Generations, AKT 6-a (Istanbul: Türk Tarih Kurumu, 2010). 
most unusual, for example, when letters discuss an ongoing legal dispute. When such an epistolary conversation is recognized, an opportunity arises to read the documents in a way that, at least in part, escapes the limitations of an anecdotal frame.

The present study arises from the rare opportunity to reconstruct a single iteration of a mundane caravan cycle through eight documents from the archive of Pūšu-kēn revolving around the business interests of Šalim-ahum, a wealthy merchant based in Aššur. These eight documents, mostly letters, form an epistolary conversation between Šalim-ahum and his representatives, ${ }^{4}$ including Püšu-kēn. The principle thread of the conversation is the progress of a caravan cycle composed of goods owned by Šalim-ahum. Previous reviews of Šalim-ahum's family firm describe the roles taken by his sons in his trade operations, ${ }^{5}$ however, this study focuses on one particular caravan cycle, not claiming to represent the entirety of Šalim-ahum's activities, nor his only mode of engaging in the trade. Contextualized within the frame of the reconstructed caravan cycle, Šalim-ahum's correspondence with his representatives can be read with an eye to the interests of the original correspondents. Among the mundane details of accounting and reporting, a social topography of the caravan cycle emerges that highlights the extent to which Šalim-ahum could interact with a wide range of merchants in the trade.

To chart the social topography of Šalim-ahum's caravan cycle, the body of this article is divided into three sections. In the first section, I present the eight documents in transliteration and translation and then provide a brief reconstruction of the caravan cycle and its development. In the second section, I address Šalim-ahum's occasional lack of precision, which suggests, against conventional wisdom, that Assyrian merchants were not always accurate in their communication, bringing some nuance to expectations of accuracy when pursuing reconstructions. In a third section, I explore the social topography of the caravan cycle by evaluating Šalim-ahum's construction of his relationships with his transporters, his buyers, and his representatives, as implied in his communication. Few persons involved in the caravan cycle had demonstrably durable relationships with Šalim-ahum, and aside from his son Dān-Aššur, who played a minor role, all other persons maintained separate balance sheets from Šalim-ahum. Moreover, Šalim-ahum's interaction with the different groups suggests that displacing risk onto other persons was an important operation for Šalim-ahum. It appears that, at least during this caravan cycle, Šalim-ahum acted as an independent wholesale merchant, sending large shipments of goods to Kaneš to sell them on credit for silver.

\section{Brief Reconstruction of Šalim-ahum's Caravan Cycle}

Šalim-ahum's epistolary conversation can be arranged in chronological order by reconstructing the single caravan cycle that occupies so much of its content. The caravan cycle can be seen as developing through three phases recorded in eight surviving documents.

4. Most often, merchants make reference to a basic commercial representative or representatives who would transact business on their behalf (ša kima). Old Assyrian merchants also had representatives for more formal legal spheres (̌̌azzuztum). On occasion, an attempt is made to differentiate these two types of agents in translations. During this particular caravan cycle, none of the agents/representatives that Šalimahum used acted the role of a šazzuztum, therefore I assume that they were functioning only as ša kima representatives during this period.

5. Sharing a name with a former Assyrian ruler, Šalim-ahum's wealth suggests he may have been related to the royal family. Šalim-ahum's activities are manifest largely both through the documents of Pūšu-kēn's archive (excavated by locals before ca. 1920 and by Hrozný in 1925) and through an archive associated with his sons (texts excavated in 1970 and published partially in AKT 3). The structure of Šalim-ahum's family firm received treatment in both J. G. Dercksen's single review of AKT 1, 2, and 3 in JESHO 41 (1998), 220-24, and C. Michel, Correspondance des Marchands de Kanish, LAPO 19 (Paris: CERF, 2001), 403-18. Pūšu-kēn's dossier of correspondence with Šalim-ahum is the largest in his archive. Because his archive was studied early on (P. van der Meer, Une correspondance commerciale assyrienne de Cappadoce [Rome: Imprimierie Pie X, 1931]), he is one of the most recognizable merchants from the Old Assyrian trade. Like Šalim-ahum, Püšu-kēn seems to have been well connected to the highest echelons of Old Assyrian society, handling business for the Assyrian king on occasion (POAT 18; KTS 130 ). Pūšu-kēn wielded power prominently in certain sessions of assemblies in Kaneš (AKT 6a 111). For a discussion of Pūšu-kēn's family, see G. Kryszat, Zur Chronologie der Kaufmannsarchive aus der Schicht 2 des Kärum Kaneš, OAAS 2/PIHANS 99 (Leiden: Nederlands Instituut voor het Nabije Oosten, 2004), 40-50. 
In the first phase, Šalim-ahum initiated the caravan cycle by shipping goods to Anatolia from his location in Aššur. Šalim-ahum produced multiple bills of lading for the several bundles of cargo he entrusted to his various contracted drivers, including Nür-Ištar's bill, which survives (1-CCT $24 \mathrm{~b} / 5 \mathrm{a}) .{ }^{6}$ In the second phase, when the drivers arrived in Kaneš, Šalim-ahum's representatives accepted his goods, paid import duties, settled accounts with the drivers, and sold some of the goods on credit to buyers. The representatives composed a number of documents, including a caravan account sent to Šalim-ahum explaining when the silver from different sales would come due. Pūšu-kēn's archival copy of the letter, which he kept in Kaneš, survives (2-Prag I 426). The representatives were not able to sell all the goods immediately, and when they later sold the remainder, they reported it to Šalim-ahum, and Šalim-ahum acknowledged receipt of the news. This can be read in a letter from later in the caravan cycle (6-TC 323 ).

In the third phase, beginning after the first portion of goods was sold on credit, Šalim-ahum attentively tracked the collection of the silver due to him and pestered his representatives to send his silver. Even before receiving the caravan account, Šalim-ahum was urging his representatives to sell his goods and included reminders to collect and send funds pertinent to other concurrent business (3-POAT 19). Soon after receiving the caravan account (2-Prag I 426), Šalim-ahum wrote to remind the representatives to collect the first maturing claim on silver (4-TC 1 14). Thereafter, Šalim-ahum's representatives collected most of the silver he had requested and sent the funds to Aššur, recording their actions in a memo (5-VS 26 130). Šalim-ahum acknowledged receiving those funds with a letter outlining the running balance his representatives owed him (6-TC 323 ). The representatives continued to collect claims as they came due and again sent another shipment of silver to Šalim-ahum; their copy of the letter sent with the silver survives (7-CCT $550 \mathrm{~b}$ ). When he received the silver, Šalim-ahum again took stock of the running balance between him and his representatives and reminded them to collect the remaining claims maturing in the near future (8-BIN 4 26). At this point, the stream of documentation breaks off. Whether or not Šalim-ahum received the remainder of his outstanding claims is unknown.

Not all of the eight documents are letters in the strictest sense. Though styled as a letter, the bill of lading (1-CCT 2 4b/5a) had a legal function. Likewise, the record Püšu-kēn and the representatives kept for themselves (5-VS 26 130) was not created as part of a missive. However, both documents can be considered evidence of the epistolary conversation conducted by Šalim-ahum and his representatives, and are included here as pieces of that exchange. Translation and transliteration of the texts with brief notes pertinent to the reconstruction precede a discussion of the caravan cycle as far as it can be followed.

\section{1-CCT $24 b / 5 a(B M 113421)^{7}$}

${ }^{1} u m-m a$ Ša-lim-a-hu-um-ma ${ }^{2} a-n a$ La-qé-ep ${ }^{3} \dot{u} P u-s ̌ u-k e-e n_{6} q i ́-b i_{4}{ }^{*} m a^{4} 26$ ku-ta-ni SIG $_{5}$-tim ${ }^{5}$ wa-at-ru-tim ku-

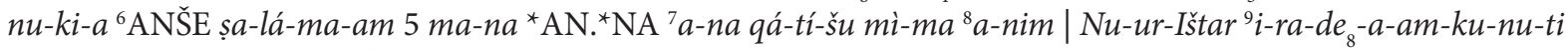

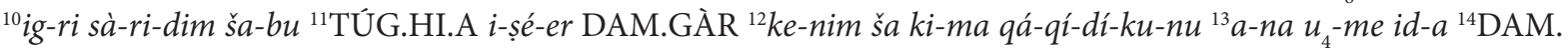
GÀR-ku-nu (rev.) ${ }^{15} l u$ ke-en 61 ITU.KAM 2 ITU.KAM ${ }^{16} l a$ tù-šé-qá-ra ANŠE ${ }^{17} i s ̌$-tí TÚG.HI.A e-mì-da ${ }^{18} a$-ṣé-er AN.NA-ak qá-tí-šu ${ }^{19} \check{s} a$ DUMU I-dí-Ištar ša $\mid 5 m a-{ }^{*} n a{ }^{20}$ AN.NA URUDU a-na A-mu- ${ }^{*} r i-{ }^{*} i m{ }^{21} a$-dí-in ù šu-ut

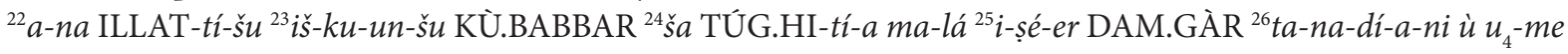
${ }^{27}\left[\right.$ té]-er-ta-ku-nu za-ku-tum ${ }^{28}$ li-li-kam

${ }^{1-3}$ Šalim-ahum to Lā-qēpum and Pūšu-kēn: ${ }^{4-9} 26$ very fine kutānum textiles under my seal a black donkey, and 5 minas of tin for his disposal-Nūr-Ištar transports all this to you (pl.). ${ }^{10}$ The wages of the donkey driver are

6. To facilitate keeping track of the different documents from the caravan cycle, I will refer to each document by its order in the reconstructed sequence in bold (1 through 8 ), followed by its publication designation and, where appropriate, line number, for example: (1-CCT 2 $4 \mathrm{~b} / 5 \mathrm{a}: 4-12)$.

7. Edition and Study: G. R. Driver, "Studies in Cappadocian Tablets," RA 24 (1927) 161-62; van der Meer, Correspondance, no. 27. 
satisfied. ${ }^{11-13}$ Sell the textiles on credit to a merchant as reliable as yourselves. ${ }^{14-15}$ Your merchant must be reliable. ${ }^{15-16}$ Do not make (the merchandise) too expensive (for) a one or two month (credit purchase). ${ }^{16-17}$ Combine the donkey with the textiles (for sale). ${ }^{18-23}$ In addition to the tin at his disposal, i.e., at the disposal of Idī-Ištar's son, I gave (him) copper worth 5 minas of tin for Amurrum, and he himself put it in his caravan. ${ }^{23-28}$ Let your full report come concerning the silver (paid) for my textiles, how much you placed on the merchant, and the terms.

18-23: The interpretation of Nūr-Ištar's role in this sentence is difficult and the translation here is admittedly awkward. There lies two possibilities for Idī-Ištar's son: 1) He added some additional tin in addition to the tin at Nür-Ištar's disposal, and separate from the copper mentioned afterward. In this case a conjunction would be appreciated, but its absence is not determinative. 2) He is the same person as Nür-Ištar because the ša clause is an appositional description of the tin at his disposal. I propose reading the document with the understanding that Nür-Ištar is the son of Idī-Ištar (1. 19). That is, the bill of lading is entirely concerned with Nūr-Ištar's cargo, written when the cargo was packed and sealed just before the caravan departed. I favor this interpretation because the bill of lading traveled with the caravan and therefore more slowly than other communications; it would be a poor medium to communicate information not directly connected to the specific cargo with which it travelled. Against this, it must be noted that there are no attested patronym formulae expressing Nūr-Ištar son of Idī-Ištar, though the name is not very common. Two other persons are attested with the name: Nūr-Ištar son of Ilabrat-bāni ( $A K T$ 3 43:24, b/k 95:1) and Nūr-Ištar son of Šū-Ǐstar (TPAK 1 105:7).

20: A-mu-ri-im. Elsewhere written MAR.TU and ${ }^{\mathrm{d}}$ MAR.TU. To be located near Nehriya. ${ }^{8}$ For an instance of copper paid to Amorites, see CCT $41 \mathrm{~b}$.

22-23: $a$-na ILLAT-tí-šu iš-ku-un-šu. Cf. other examples where it likely refers to caravan as enterprise (CCT 4 1a:22-32; CCT 4 1b:19-24; CCT 4 1a:22-32).

\section{2-Prag I $426^{9}$}

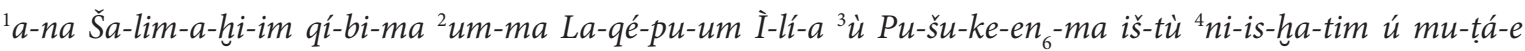
${ }^{5} n u$-șa-ḩi-ru-ni 2 GÚ 2 ma-na 8 GÍ[N] ${ }^{6}$ AN.NA-ak-[kà] iz-ku-a-am ${ }^{7} 27$ TÚG ku-ta-ni 4 TÚG ša li-wi-t[im] ${ }^{8} m i-$ ma a-nim DUMU E-ra-di ${ }^{9} i p-q i ́-i d-n i-a-t i ́ \mid$ ni-kà-sí ${ }^{10} i \check{s}$-tí-šu a-dí-ni | la ni-sí ${ }^{11}$ ANŠE.HI-ru-kà me-tù ŠÀ.BA 20 TÚG $k u$-ta-ni ${ }^{12} 1 / 2$ ma-na.TA 4 TÚG šu-ru-tum 15 GÍN.TA ${ }^{13} 7$ GÍN.TA $a$-na AN.NA-ki-kà ${ }^{14} n u$-mì-id-ma $28^{1 / 3}$ ma-na 7 GÍN ${ }^{15} \mathrm{KUU.BABBAR} i$-șé-er DAM.GÀR a-na $u_{4}$-me! ${ }^{16} p a ́$-tí-ú-tim | na-dí ší-tí TÚG ku-ta-ni-kà ${ }^{17} 7$ TÚG! $a$-ni-kà-sí-kà na-ad-ú ${ }^{18} 2$ GÚ 10 ma-na AN.NA 4 TÚG li-wi-tum ${ }^{19} 5$ TÚG ku-ta-ni 1 ANŠE șa-lá-ma-am ${ }^{20} \check{s} a$ šé-ep A-šur-mu-ta-bi-il ${ }_{5}^{21} 26$ TÚG ku-ta-nu 1 ANŠE șa-lá-mu-um ${ }^{22} \mathrm{Nu-ur-Ištar} \mathrm{ir-de}$ TÚG ni-is-ḩa-tum (lo.e.) ${ }^{24} \dot{u} 1$ GÍN KÜ.BABBAR né-pu-ul| 3 TÚG.HI.A ${ }^{25} a$-ši-mì-im 1 TÚG iš-tí d NIN.ŠUBURba-ni ${ }^{26}{ }_{s ̌ i}$-tí TÚG.HI-tí-kà 26 TÚG.HI.A iz-ku-ú-nim (rev.) ${ }^{27} i$-na 2 GÚ 10 ma-na AN.NA ${ }^{28}$ ša šé-ep A-šur-mu-tabi-il ${ }_{5}^{29} 4$ ma-na ni-is-ḩa-tum 4 5/6 ma-na 4! GÍN ${ }^{30} m u$-țá-ú| iš-tù AN.NA-ak q[á]-tim ${ }^{31}$ gám-ru 71³ ma-na 7 GÍN

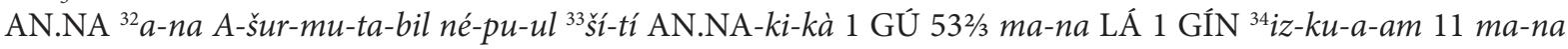
AN.NA ${ }^{35}[\check{s}] a$ ILLAT-at A-šur-ma-lik ${ }^{36}\left[\right.$ É] kà-ri-im ni-il ${ }_{5}-q e ́-m a^{37} a-l i-b i_{4}$ AN.NA-ki-kà ni-dí ${ }^{38}$ ŠUNIGIN 2 GÚ 42/3 ma-na LÁ 1 GÍN ${ }^{39}$ AN.NA-ak-kà 7 GÍN.TA ${ }^{40} 26$ TÚG ku-ta-nu $1 \frac{1}{2}$ ma-na.TA ANŠE ${ }^{41} k i-m a ~ 1 \frac{1}{2}$ ma-na ŠUNIGIN KÙ.BABBAR ša AN.NA ${ }^{42}$ TÚG.HI.A ú ANŠE 31 ma-na 18¹⁄2 GÍN ${ }^{43} i$-ṣé-er DAM.GÀR a-na $u_{4}$-me pá-tí-ú-tim

8. See Veenhof and Eidem, Mesopotamia: The Old Assyrian Period, 97, n. 426. See also, K. Nashef, Die Orts- und Gewässernamen der altassyrischen Zeit, RGTC 4 (Wiesbaden: Reichert, 1991), 10. On ammurum as a verbal adjective describing silver, see J. G. Dercksen, The Old Assyrian Copper Trade in Anatolia, PIHANS 75 (Istanbul: Nederlands Historisch-Archaeologisch Instituut, 1996), 164 n. 512, T. Sturm, "kaspum ammurrum: Ein Begriff der Silbermetallurgie in den Kültepe-Texten," UF 27 (1995) 487-503.

9. Edition and Translation: K. Hecker, G. Kryszat, and L. Matouš, Kappadokische Keilschrifttafeln aus den Sammlungen der Karlsuniveristät Prag (Prag: Filozofická Fakulta Univ. Karlovy, 1998), 3-5. Translation: K. Hecker, "Altassyrische Briefe," in Texte aus der Umwelt des Alten Testaments Neue Folge Band 3, ed. B. Janowski and G. Wilhelm (Gütersloh: Gütersloher Verlaghaus, 2006), 79-80. 
${ }^{44} n a$-dí 4 TÚG ša li-wi-tim a-[na] ${ }^{45}[n] i-k a ̀-s i ́-k[a ̀ ~ n] a-a d-u ́ ~ i-n a{ }^{46} 6$ GÚ 30 [m]a-na AN.[NA] ša šé-[ep] ${ }^{47} A h-\check{a} a-l i m$ [2]1 ma-[n]a ni-is-[ha-tum] ${ }^{48} 3$ ma-na 10 GÍN mu-táa-ú ${ }^{49}$ ší-tí A[N].NA-ki-kà 6 GÚ 5 [5/6 ma-na] ${ }^{50}$ ŠÀ.BA 5 GÚ 42/3 ma-na ${ }^{51} 8$ GÍN.TA 50 TÚG ku-ta-nu (u.e.) ${ }^{52} q a ́$-dum šsu-ru-tim ša iṣ-bu-[tù] ${ }^{531} / 3$ ma-na.TA $a$-na $u_{4}$-me-e (le.e.) ${ }^{54} q u$-ur-bu-tim 542/3 ma-na 5 GÍN ${ }^{55}$ [K]Ü.BABBAR i-șé-er DAM.GÀR na-dì

${ }^{1-3}$ To Šalim-ahum, from Lā-qēpum, Ilī-ālum, and Pūšu-kēn: ${ }^{3-6}$ After we deducted the excise duty and deficiencies, they (the palace) cleared your 122 minas 8 shekels tin. ${ }^{7-9} 27$ kutānum textiles, 4 wrapping textiles (and your tin) -all this Erra-idì's son entrusted to us. ${ }^{9-10}$ We have not yet settled accounts with him. ${ }^{11}$ Your donkeys died. ${ }^{11-16}$ Thereof, we bundled 20 kutānum textiles at $1 / 2$ mina each, 4 šurum textiles at 15 shekels each, a 7 shekel rate for your tin, and (this lot) is placed on a merchant on long terms for 28 minas 27 shekels of silver. ${ }^{16-17}$ The remainder of your kutānum textiles-7 textiles-are deposited to your account. ${ }^{18-20} 2$ talents 10 minas of tin, 4 wrapping textiles, 5 kutānum textiles, 1 black donkey are from the charge of Aššur-muttabbil. ${ }^{21-22 N u ̄ r-I s ̌ t a r ~ d r o v e ~ h e r e ~} 26$ kutānum textiles and 1 black donkey. ${ }^{22}$ One donkey died. ${ }^{23-24}$ Thereof, the excise duty was $1 \frac{1 / 2}{2}$ textiles, and we balanced 1 shekel silver. ${ }^{24-25} 3$ textiles for purchases. ${ }^{25} 1$ textile is with Ilabrat-bāni. ${ }^{26}$ They cleared the remainder of your textiles-26 textiles. ${ }^{27-29}$ From the 2 talents 10 minas of tin of the charge of Aššr-muttabbil, the excise duty was 4 minas. ${ }^{29-30} 4$ minas 54 shekels (of tin) were deficient. ${ }^{30-32} \mathrm{After}$ the "hand tin" was spent, we balanced 7 minas 27 shekels of tin to Aššur-muttabbil. ${ }^{33-34}$ They cleared the remainder of your tin: 1 talent 53 minas 39 shekels. ${ }^{34-37} \mathrm{We}$ took 11 minas of tin from the caravan of Aššur-mālik at the colony office and placed it in your tin. ${ }^{38-41}$ In sum, (the lot was) 2 talents 4 minas 39 shekels of your tin at a rate of 7 shekels, 26 kutānum textiles at a $1 / 2$ mina each, a donkey for $1 / 2$ mina. ${ }^{41-44}$ The total silver for the tin, textiles, and the donkey: 31 minas $18 \frac{1}{2}$ shekels, is placed on a merchant on long terms. ${ }^{44-45} 4$ textiles for wrapping are deposited to your account. ${ }^{45-47}$ From the 6 talents 30 minas of tin of the charge of Ah-šalim, the excise duty was 21 minas. ${ }^{48} 3$ minas 10 shekels (of tin) were missing. ${ }^{49} \mathrm{The}$ remainder of your tin was 6 talents 5 minas 50 shekels. ${ }^{50-55}$ Thereof, 5 talents 4 minas 40 shekels (of tin) at a rate of 8 shekels, 50 kutānum textiles, together with šurum textiles, which they seized at 20 shekels each, are placed on the merchant on short terms for 54 minas 45 shekels of silver.

8: DUMU E-ra-dí. The original edition and Hecker's translation of the text suggest that DUMU E-ra-dí is Aššurmuttabbil son of E-ra-dí (as found in Prag I 633:21') and the same Aššrur-muttabbil as mentioned in 1.20 of this document. However, Prag I 633 is entirely unrelated to this matter. And DUMU E-ra-dí and Ǎšur-muttabbil can be safely distinguished within the document: the two transported different cargoes, and while the representatives had not yet balanced DUMU E-ra-dí by the time of composition (1l. 7-10), they had already balanced Ašsurmuttabbil (1l. 30-32).

\section{3-POAT $19\left(\right.$ L 29-574) ${ }^{10}$}

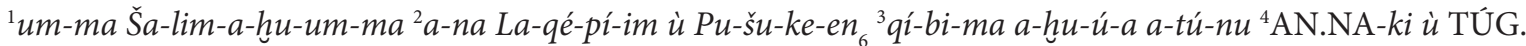

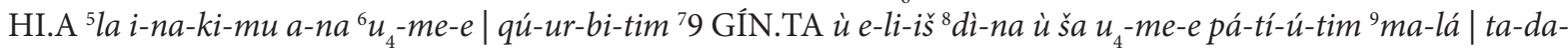

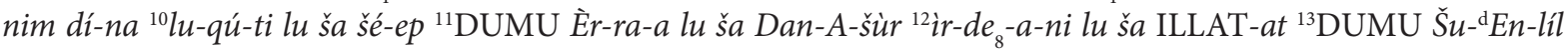

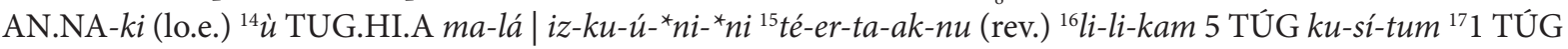

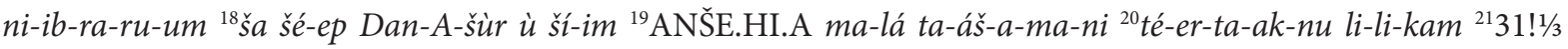
ma-na 7 GÍN KÙ.BABBAR ${ }^{22}\left[u_{4}\right]$-me-e ša ta-áš-pu-ra-ni ${ }^{23}[10]$ ma-na 10 GÍN KÙ.BABBAR ša me-er-e ${ }^{24} A$-šùr

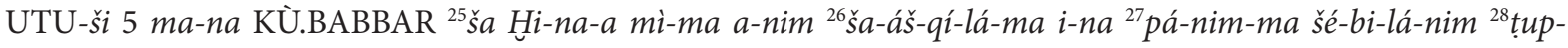
pu-um ša ší-ma-at ${ }^{29} A$-šùr-i-mì-tí i-na Hu-ra-ma ${ }^{30} i \check{s}$-tí Ša-lim-A-šùr DUMU En-um-A-[šùrr] ${ }^{31} i$-ba-ši šu-up-ra-ma tup-pá-am ${ }^{32} l u$-ub-lu-ni-ku-nu-tí-ma (le.e.) ${ }^{33}$ tup-pá-am i-na qà-nu-e lá-wi-a-ma ${ }^{34}[d a]$-am-qí-iša-na DUMU um-

10. Copy: H. Lewy, "Old Assyrian Texts in the University Museum," HUCA 39 (1969), 32-33. Edition: W. C. Gwaltney, The Pennsylvania Old Assyrian Texts, HUCA Suppl. 3 (Cincinnati: Hebrew Union College-Jewish Institute of Religion, 1983), 56-59. 
me-a-nim ${ }^{35}[k e]$-nim pí-iq-da-ma lu-ub-lam a-na ${ }^{36} w a-b i_{4}-i l_{5}$ tup-[pi]-im KÙ.BABBAR 1 [GÍN] i-na [KÙ.BABBAR] ${ }^{37} d \dot{\imath}-n a-s ̌ u-u m[\mathrm{x}$ x ] $\grave{u}$ ? ša? [ $\mathrm{x}$ x ]

1-3̌̌salim-ahum to Lā-qēpum and Pūsu-kēn: ${ }^{3-5} \mathrm{My}$ dear brothers, my tin and textiles should not be stocked up. ${ }^{5-9}$ Sell (the tin) on short terms at a rate of 9 shekels or higher; otherwise, sell as much as can be sold on long terms. ${ }^{10-16}$ Let your report come as to how much of my goods-those from the cargo of Erraya’s son (Aššur-mālik), those that Dān-A ššur drove, and those from the caravan of Šü-Enlil's son-(that is) my tin and textiles, cleared (the palace). ${ }^{16-20}$ Let your report come regarding the five kusitum-robes, the 1 nibrarum-textile from the cargo of DannAššur, and the price of the donkeys, as much as you bought. ${ }^{21-27}$ As for the 30 minas 27 shekels of silver on terms about which you wrote me-10 minas 10 shekels of silver of the sons of Aššur-šamši and 5 minas of silver of Hुinnaya-have all this paid and send it to me at the first opportunity. ${ }^{28-31} \mathrm{~A}$ tablet recording the will of Aššr-imitti is with Šalim-Aššur son of Ennum-Aššur in Hurrama. ${ }^{31-32}$ Send to him to have the tablet brought to you. ${ }^{33-35}$ Wrap up the tablet in straw, and carefully entrust (it) to a reliable affiliated trader so that he may bring it to me. ${ }^{35-37}$ Give a shekel of silver to the bearer of the tablet....

4: TÚG.HI.A. K. Hecker, review of Gwaltney, The Pennsylvania Old Assyrian Texts in AfO 31 (1984) 84, reads TÚG.HI- $a$, "my textiles;" the least-marked form is preferred here.

12: ir-de $-a-n i$. See Hecker, ibid., 84.

13: DUMU Šu-En-lil. This person cannot be positively identified with Ennum-Aššur son of Šū-Enlil (5-VS 26 130:4'-5'; 6-TC 3 23:22-23). Four other persons are documented with Šū-Enlil as father in the Old Assyrian corpus: two attested commonly (Aššur-nādā (brother of Ennum-Aššur), and Aššur-taklāku (kt a/k 381:22-23, courtesy S. Bayram) and two attested only once (Aššur-mālik [kt c/k 1502:20, courtesy J. G. Dercksen] and PuzurAššur [TC 3 41:28-29]).

21: 31!13 ma-na 7 GÍN KÜ.BABBAR. Number collated on photo. From this total we deduce that the debt for which Hinnaya was responsible was 21 minas 17 shekels.

33-35: Translation follows Veenhof, Aspects, 28.

\section{4-TC $114(A O 7063)^{11}$}

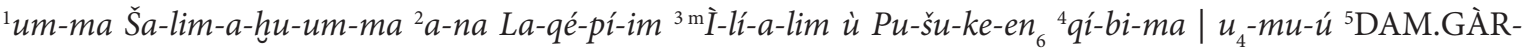

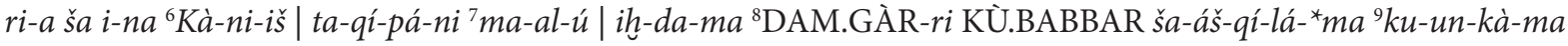
i-na ${ }^{10}$ pá-nim-ma $\mid$ šé-bi-lá-nim ${ }^{11 \mathrm{~m}}$ Dan-A-šùr ù a-ḩu-šu ${ }^{12}$ țur-da-nim $\mid i-n a{ }^{13} \mathrm{DAM}$.GÀR | ša $u_{4}$-mu-šu ${ }^{14} e$-tí-qú-ni

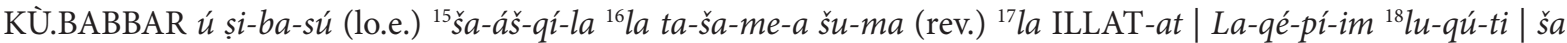
ta-qí-pá-ni ${ }^{19} u_{4}-m u-u ́ \mid$ DAM.GÀR-ri ${ }^{20} \check{u} u-n u-t i ́ \mid a-h u-r u-n i{ }^{21} \check{s} a$ mì-ma| DAM.GÀR-ri-a ${ }^{22} u_{4}-m u$-šu-nu|ma-al-ú ${ }^{23} 10^{1 / 2}$ ma-na KÜ.BABBAR ša me-er-e ${ }^{24} A$-šur-UTU-ši DUMU Ib-ni-i-lí ${ }^{25}{ }^{5} a$ ki-ma šu-nu-tí ${ }^{26} L a-q e ́-p a ́-a m ~ e-p u-l u$

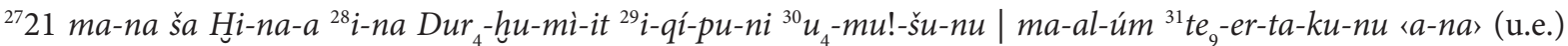
${ }^{32} l i-l i-i k$

${ }^{1-4}$ Šalim-ahum to Lā-qēpum, Ili-ālum, and Pūsu-kēn: ${ }^{4-7}$ The term of my merchant to whom you extended credit in Kaneš is full. ${ }^{7-10}$ Take care to make my merchant pay the silver, seal it, and send it to me in the first (transport). ${ }^{11-12}$ Dispatch Dān-Aššur and his brother to me. ${ }^{12-15}$ From the merchant whose term has expired, make him pay the silver and its interest. ${ }^{16}$ Don't listen (to the interest). ${ }^{16-22}$ Except for the caravan of Là-qēpum, my goods which you sold on credit, the terms of the merchants-those which are still running, of all of my merchants-their terms are full. ${ }^{23-26}$ (As for the) 101/2 minas of silver of the sons of Ǎšur-šamšì son of Ibni-ilī, their representatives will

11. Translation and Study: B. Landsbeger, Assyrische Handelskolonien in Kleinasien aus dem dritten Jahrtausend, Der Alte Orient 24/4, (Leipzig: Hinrichs, 1925), 18; J. Lewy, Studien zu den altassyrischen Texten aus Kappadokien (Berlin: Lewy, 1922), 77-80; van der Meer, Correspondance, no. 24. The last author recognized a connection between this text and 8-BIN 426. 
balance Lā-qēpum. ${ }^{27-30} 21$ minas which Huinnaya extended as credit in Durhumit, their terms are full. ${ }^{31-32}$ Let your report come.

11: Dān-Aššur's brother, to which Šalim-ahum refers, is most likely Ennam-Aššur.

16: la ta-ša-me-a. See note to 6-TC 3 23:30-31.

\section{5-VS $26130(\text { VAT 9264) })^{12}$}

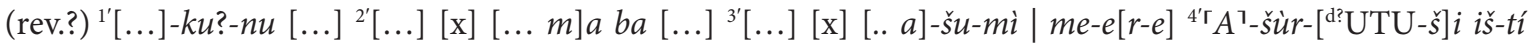

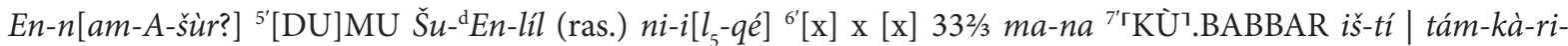

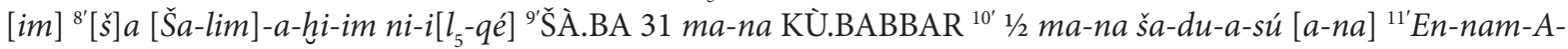

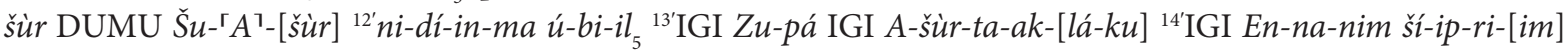

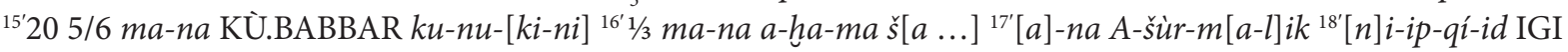
$[(\ldots)]$ (remainder broken)

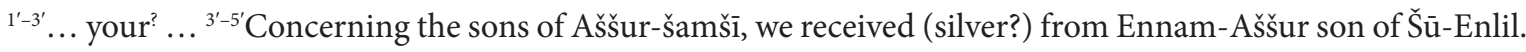
$6^{\prime}-8^{\prime}[\ldots]$ We received 33 minas 40 shekels from the merchant of Šalim-ahum. ${ }^{9^{\prime}-12^{\prime}}$ Thereof, we gave 31 minas of silver,

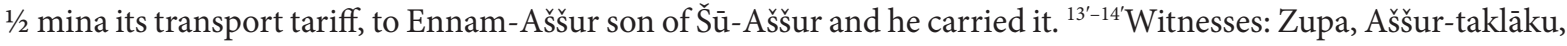
Ennānum the scribe. ${ }^{15^{\prime}-18^{\prime}}$ We entrusted to A ššur-mālik 20 minas 50 shekels of silver under our seal, separately 20 shekels which $[\ldots] .{ }^{1{ }^{\prime}}$ Witnesses: $[\ldots]$

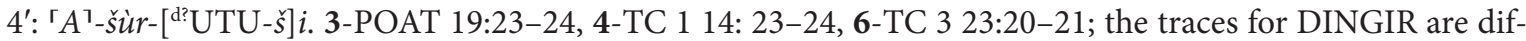
ficult.

5': En-n[am-A-šùr] [DU]MU Šu- ${ }^{\mathrm{d}} E n-l i ́ l$. See also 6-TC 3 23:22-23 and kt 94/k 1174: 1, 4 (courtesy M. T. Larsen). He has a brother, Aššur-nādā, who elsewhere owes $1 / 3$ mina silver to Pūšu-kēn and company; Ennam-Aššur asks for a month or two to pay, after which Pūšu-kēn and company may go to the house of a merchant and take out a loan against both brothers (kt 88/k 40:3, courtesy I. Albayrak). Ennam-Aššur is elsewhere involved in a dispute with Ennam-Aššur son of Lā-qēpum, who is also known to be associated with Pūšu-kēn and recruited by Šū-Huubur (Adana 237d).

$6^{\prime}:[\mathrm{x}] \mathrm{x}[\mathrm{x}]$. This section is not likely to express a number of talents of silver in conjunction with the $33^{2} / 3$ minas of silver. The representatives sent a total of 53 minas of silver from this collection (6-TC 3 23:10-14).

\section{6-TC $323($ AO 9290)}

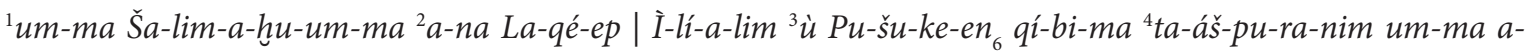

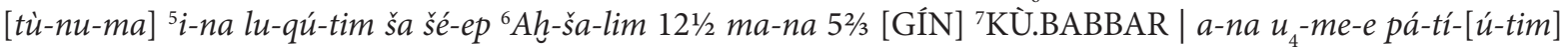
${ }^{8} i$-șé-er DAM.GÀR | (Ras.) ke-nim! [na-dí] ${ }^{9} 54^{2} / 3$ ma-na 5 GÍN KÙ.BABBAR [ša $u_{4}$-mu-šu] ${ }^{10} m a-a l-u ́-n i$ ŠÀ $31 \frac{1}{2}$ ma-[na] ${ }^{11} q a ́$-dum $\mid \check{s} a$-du-e-tim [Šu-Sú-en ${ }_{6}{ }^{12} u b$-lam 21 ma-na 10 GÍN [KÙ.BABBAR] ${ }^{13} A$-šur-ma-lik ub-lam [̌̌́-

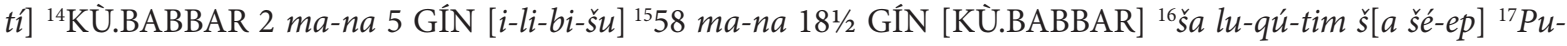
šu-ke-en ${ }_{6}\left[281 / 3\right.$ ma-na 7 GÍN] ${ }^{18} \check{s} a$ lu-qú-tim [ša šé-ep] (lo.e.) ${ }^{19}$ DUMU E-ra-di [10 ma-na $\left.10 \mathrm{GÍN}\right]{ }^{20} \mathrm{KUU.BABBAR}$ ša me-er-[e] (rev.) ${ }^{21} A$-šùr-UTU-ši ${ }^{\ulcorner} a$ ?? [-na? ... ] ${ }^{22} i-m a-d u-d u{ }^{\top} \mathrm{x}^{\top}$ [ $\mathrm{x}$ ? En?-nam?-A?-šur?] ${ }^{23} \mathrm{DUMU}$ Šu-d En-líl La-

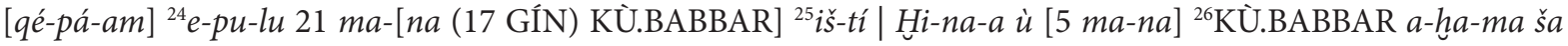

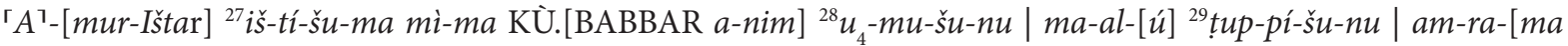
ša $\left.u_{4}-m u-s ̌ u-n u\right]{ }^{30} e-t i-q u ́-n i \mid ~ s ̦ i ́-i[b-t a ́ m]{ }^{31} l a$ ta-ša-me-a $\mid \mathrm{KÙ}$.[BABBAR] ${ }^{32} p a ́-n i-a-m a \mid$ ša ta-[al-qé-a-ni] ${ }^{33} k u-u n-$

12. Brief notes: K. Veenhof and E. Klengel-Brandt, Altassyrische Tontafeln aus Kültepe Texts und Seigelabrollungen, VS 26 (Berlin: Gebr. Mann, 1992), 28. 


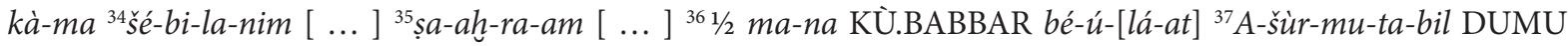

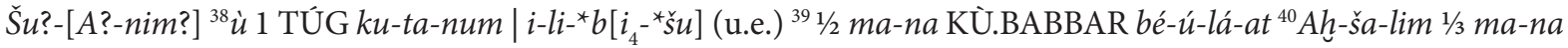

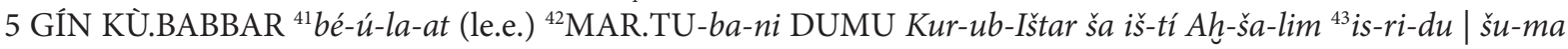
lá iš-qú-ul ša-áš-qí-lá-šu

1-3ك̌alim-ahum to Lā-qēpum, Ili-ālum, and Pūšu-kēn: ${ }^{4-8}$ You wrote to me, "12 minas 352/3s shekels of silver are placed on a trustworthy merchant on long terms from the goods in Ah-šalim's cargo." ${ }^{9-12} \mathrm{As}$ for the 54 minas 45 shekels of silver that are due, thereof Šü-Suen brought me $31 \frac{1 / 2}{2}$ minas together with the transport tariff. ${ }^{12-13}$ Aššurmālik brought me 21 minas 10 shekels of silver. ${ }^{13-14}$ The rest of the silver-2 minas 5 shekels-he owes. ${ }^{15-17} 58$ minas 18 $1 / 2$ shekels of silver, (the proceeds) of the goods of the cargo of Püšu-kēn. ${ }^{17-19} 28$ minas 27 shekels (of silver, the proceeds) of the goods of the cargo of Erra-iddi(n)'s son. ${ }^{19-24} 10$ minas 10 shekels of silver of the sons of Aššur-šamšĩ ... they will measure out. [PN? (and Ennam-Aššur)?] son of Šū-Enlil will balance (it) to Lā-qēpum. ${ }^{24-27} 21$ minas (17 shekels) silver with Hinnaya and 5 minas of silver separately of Amur-Ištar are with him. ${ }^{27-28} \mathrm{All}$ this silver, their terms are full. ${ }^{29-31}$ Inspect their tablets, so that you don't listen to the interest of those who are past due. ${ }^{31-35}$ The previous silver that you received, seal and send it here. ... ${ }^{36-38} \frac{1}{1 / 2}$ mina silver is the working capital of Aššur-muttabbil son of [Šū-Anim]; he also owes 1 kutānum textile. ${ }^{39-40} 30$ shekels of silver is the working capital of Ah-šalim. ${ }^{40-43}$ As for the 25 shekels of silver, the working capital of Amurrum-bāni son of Kurub-Ištar, who drove with Ah-šalim, if he did not (already) pay, have him pay.

11: [ك̌́u-Sú-en ${ }_{6}$. 8-BIN 4 26:18-21 where Šū-Suen and the son of Šü-Aššur are recorded bringing the same packet of silver. Šalim-ahum also reports the receipt of another packet of silver from Dān-Aššur totaling 31 minas 15 shekels with 30 shekels as transport tariff in 8-BIN 4 26:24-27. Reconstructing Šü-Suen is preferred over DānAšsur because of the otherwise consistent order between the listing of silver received here and in 8-BIN 426 (see Table 4 below) and because Dān-Aššur is also mentioned with an additional 2 minas of silver there.

13-14: [̌̌i-tí] KÙ.BABBAR 2 ma-na 5 GÍN [i-li-bi-šu] - by this Šalim-ahum credited all the monies received towards the debt of 54 minas 45 shekels.

17: [281/3 ma-na 7 GÍN]. See 3-POAT 19:21-27.

19: [10 ma-na 10 GÍN]. See 3-POAT 19:23.

20-24: This is a difficult section. To whom would Aššur-šamšìss sons have "measured out" the silver? The verb madädum most often refers to measuring out of grain in the Old Assyrian corpus, although for an instance of silver being weighed out see: KÙ.BABBAR ù șí-ba-tù-šu i-séer A-zu-da i-mí-dí-id (CCT 4 3b:4-6). En?-nam?-A?-šur? is restored hesitantly; the letter writer may have been satisfied with DUMU $\breve{S} u$-En-lil. However, $e$-pu-lu must be plural as no governing independent clause can be found to suggest a subjunctive. Ennam-Aššur is known to act in some way as representative, $\mathbf{5}$-VS 26 130:4'.

30-31: șibtam lā tašammeā "do not listen to the interest"-I interpret this phrase as Šalim-ahum instructing his representatives to not allow the debtors to postpone payment by paying penalty interest in the interim. Thus the interest, or the silver paid as interest, effectively says on behalf of the debtor "I'm not paying yet," the message Šalim-ahum least wants to hear. This same statement could be read to mean that the representatives were to collect the principal amount at the expense of the accumulated interest, thus "don't worry about the interest." However, it seems useful to separate a sense of "do not listen to" from a sense of "don't worry about." In this letter, the debts to which Šalim-ahum referred were just coming due, not past due, and the interest was relatively small. Instead, the tone of the letters indicates that Šalim-ahum's top priority was to collect the silver promptly; the greatest danger that interest posed was delaying that result. ${ }^{13}$

13. For the personification of inanimate objects, including silver, in Old Assyrian, see K. R. Veenhof, "'Dying Tablets' and 'Hungry Silver', Elements of Figurative Language in Akkadian Commercial Terminology," in Figurative Language in the Ancient Near East, ed. M. Mindlin, et al. (London: University of London, School of Oriental and African Studies, 1987), 99 n. 35. 
37: Šu?-[A?-nim?] - See TC 1 63, ICK 1 187. Of the eight persons in the Old Assyrian corpus known as father of Aššur-muttabbil, only Šū-Anim is possible if the wedge going into the break is vertical. If the wedge is horizontal (cf. line $22 i-m a-d u$ - $d u$ on the copy), then other possibilities exist (Ikuppi-Aššur, Iddin-abim, I-da-ZU).

\section{7-CCT $550 b(B M 115054)^{14}$}

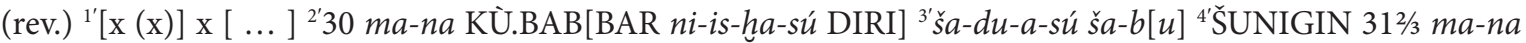

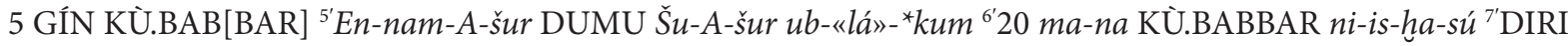
ša-du-a-sú ša-bu ${ }^{8}$ ŠU.NIGIN 21 ma-na 10 GÍN KÜ.BABBAR ${ }^{9 \prime} A$-šur-ma-lik DUMU Er-ra-a ub-lá- ${ }^{*} k u m{ }^{10} 30$ mana KÜ.BABBAR ni-is-ḩa-sú ${ }^{1{ }^{1}}$ DIRI ša-du-a-sú ša-bu ${ }^{12^{\prime} \dot{u}} 2$ ma-na KÜ.BABBAR me-eh-ra-at ${ }^{13^{\prime}}[6]$ TÚG ku-ta-ni ša Dan-A-šur ${ }^{14^{\prime}}[\mathrm{x} \times \mathrm{x}]$ x KÜ.BABBAR-pí-kà $a{ }^{*}{ }^{*}$ a? (remainder broken)

${ }^{\prime} \ldots{ }^{\prime}-5^{\prime} 30$ minas of silver, its excise added, its transport tariff paid-total 31 minas 45 shekels of silver EnnamAššur son of Šū-Aššur brought you. ${ }^{6^{\prime}-9^{\prime}} 20$ minas of silver its excise added, its transport tariff paid-total 21 minas 10 shekels of silver Aššur-mālik son of Erraya brought to you. ${ }^{10^{\prime}-14^{\prime}} 30$ minas of silver, its excise added, its transport tariff paid, also 2 minas of silver the proceeds of 6 kutānum textiles of Dān-Aššur, ... your silver to ...

12-13: 2 minas of silver was the proceeds of 6 textiles which Dān-Aššur had recently brought to Kaneš (3-POAT 19:16-20; 8-BIN 4 26:24-27).

\section{8-BIN $426(N B C 1900)^{15}$}

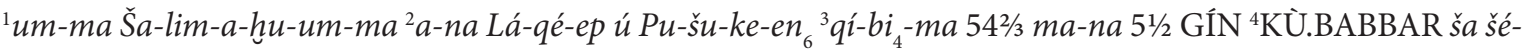

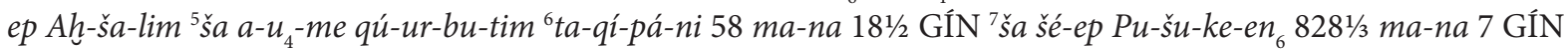

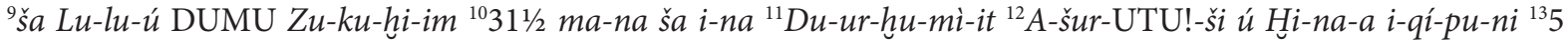
ma-na ša A-mur-Ištar ša AN.NA-ki-a ${ }^{14}$ ta-áš-pu-ra-nim um-ma a-tù-nu- $m a{ }^{15} H i$-na-a i-ša-qá-al-šu ${ }^{16} u$ té-er-tí-ni a-na Hi-na-a ${ }^{17}$ i-ta-lá-ak ŠUNIGIN 2 GÚ 58 ma-na 1 GÍN ${ }^{18 S ̌ A ̀ ~} 31$ ma-na 15 GÍN ${ }^{19} 1 / 2$ ma-na ša-du-a-sú (lo.e.) ${ }^{20} \breve{S} u$-Sú-en ${ }_{6} u ́$ DUMU Šu-A-šùr ${ }^{21} u$-lu-nim 20 5/6 ma-na (rev.) ${ }^{22} 1 / 3$ ma-na ša-du-a-sú ${ }^{23}$ DUMU E-ra-a ub-lam ${ }^{24} 31$ ma-na 15 GÍN ${ }^{1 / 2}$ ma-na ${ }^{25}{ }^{25} a$-du-a-sú 2 ma-na ${ }^{26} a$-ḩa-ma me-eh-ra-at TÚG.HI!-tí-šú ${ }^{27} D a n-A$-šùr ub-lam ${ }^{28} 41^{2 / 3}$ ma-na ${ }^{2 / 3}$ ma-na ša-du-a-sú ${ }^{29} I$ I-lí-a-lim ub-lam 18 ma-na 18 GÍN ${ }^{30} K u r-u b$-Ištar ub-lam ${ }^{31}$ ŠUNIGIN 2 GÚ 27 ma-na 18 GÍN ${ }^{32} \mathrm{KÜ.BABBAR}$ ša ub-lu-ni-ni ší-tí KÜ.BABBAR ${ }^{33} 301 / 3$ ma-na 3 GÍN ${ }^{34}$ ša $_{4}$-mu-šu e-tí-qú-ni ${ }^{35}$ șíib-tám lá ta-ša-me-a ${ }^{36} \mathrm{KUU.BABBAR}$ ša-áš-qí-lá-ma i-pá-nim-ma ${ }^{37}{\text { šé}-b i_{4}-l a ́-n i m}_{\text {ú a-șé-er }{ }^{38} \mathrm{H} i-n a-a}$ šu-up-ra-ma KÜ.BABBAR ${ }^{39} \check{s} a$ ášs-ra-kam-ma i-qí-pu-ni ${ }^{40} l u$-šé-bi -lam i-na țup-pi-ku-nu ${ }^{41} 12 ! 112$ ma-na 5 2/3 GÍN ${ }^{42} \mathrm{KÜ.BABBAR}$

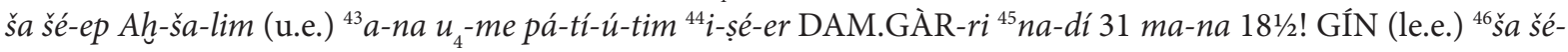
ep A-šùr-mu-ta-bi $i_{4}-i l_{5}$ ú Nu-ur-Ištar šu-ma ${ }^{47} u_{4}-m u$-šu-nu ma-al-ú KÙ ša-áš-qí-lá-ma i-pá-nim-ma ${ }^{48}{ }_{\text {śé-bi }}-l a ́-n i m$ KÙ.BABBAR ša İ-lí-a-lim ú Kur-ub-Ištar ub-lu-ni-ni ${ }^{49} m i ̀-s ̌ u-u m ~ t ̦ u p-p u-u m ~ i k-b i_{4}-i t-k u-n u$-tí-ma lá tù-še-bi-lánim

${ }^{1-3 S}$ Šalim-ahum to Là-qēpum and Pūšu-kēn: ${ }^{3-6} 54$ minas $45 \frac{1}{2}$ shekels of silver from the cargo of Ah-šalim which you extended on short terms. ${ }^{6-7} 58$ minas $181 / 2$ shekels of the cargo of Püšu-kēn, ${ }^{8-9} 28$ minas 27 shekels of Lulu son of Zukuhum. ${ }^{10-17} 31^{1 / 2}$ minas which Aššur-šamšì and Huinnaya extended on credit in Durhumit. 5 minas of Amur-Ištar. As for my tin-you wrote me, saying, "Hinnaya will pay for it and then our instructions will go to Hinnaya." ${ }^{17}$ Total: 178 minas 1 shekel (of silver). ${ }^{18-21}$ Thereof, Šù-Suen and the son of Šū-Aššur brought me 31 minas

14. Partial Translation: Larsen, Old Assyrian Caravan Procedures, 36 (1l. 1'-7', identified as CCT 5 50c). Note on the fees in the text also in L. Matouš, "Zu einer neuen Publikation kappadokischer Tafeln vom Kültepe," BiOr 16 (1959) 183.

15. Translation and study: van der Meer, Correspondance, no. 25. 
15 shekels, 30 shekels was its transport tariff; ${ }^{21-23}$ Erraya's son brought me 20 minas 50 shekels, 20 shekels was its transport tariff; ${ }^{24-27} \mathrm{Da} n$-Aššur brought me 31 minas 15 shekels, 30 shekels was its transport tariff. An additional 2 minas is the equivalent to his textiles. ${ }^{28-29} \mathrm{Il}$-ālum brought me 41 minas 40 shekels, 40 shekels was its transport tariff. ${ }^{29-30}$ Kurub-Ištar brought me 18 minas 18 shekels. ${ }^{31-32}$ Total: 147 minas 18 shekels of silver that they brought. ${ }^{32-34}$ The remainder of silver is 30 minas 23 shekels of those (debts) whose terms are past due. ${ }^{35}$ Don't listen to the interest. ${ }^{36-37}$ Have the silver paid and brought to me in the first (transport), ${ }^{37-40}$ and then write to Hinnaya so that he has the silver brought to me, which they extended on credit there. ${ }^{40-45}$ In your tablet 12 minas $35^{2 / 3}$ shekels of silver of the cargo of Ah-šalim were given to merchants on long-term credit. ${ }^{45-48}$ Have them pay 31 minas 181/2 shekels of silver of the cargo of Aššur-muttabbil and Nūr-Ištar if their terms are due, and have (it) brought to me in the first (transport). ${ }^{48-51} \mathrm{As}$ for the silver which Ilī-âlum and Kurub-Ištar brought to me, why is it that the tablet has become too difficult for you to send to me?

41: 12!. Collated; see 6-TC 3 23:6. Some other goods must have been sold along with the tin. If the 61 minas 10 shekels of tin from Ah-šalim's cargo sold at an 8-shekel rate the yield would have been 7 minas 38.7 shekels of silver; if it sold at a 7-shekel rate the yield would have been 8 minas 44.3 shekels of silver.

45: $18^{1 / 2} !$ GÍN. Collated by the author.

48-51: The intent of this comment is uncertain. Perhaps Šalim-ahum expected more documentation with the shipment? If the comment was a sarcastic jab, then Šalim-ahum must have been alluding to not having received a tablet in conjunction with the silver sent with the two transporters mentioned. This merely serves to underline Šalim-ahum's expectation of documentation at every stage of the process.

\section{Phase One: Shipping Off the Goods}

Šalim-ahum began this caravan cycle by purchasing almost 11 talents of tin, roughly sixty textiles, and seven donkeys with their tack in Aššur. He contracted with five transporters, or drivers, ${ }^{16}$ to take the goods: Nūr-Ištar, Aššur-muttabbil, Ah-šalim, and Amurrum-bāni, and a man Šalim-ahum referred to as Erra-idī’s son. Nūr-Ištar's bill of lading (1-CCT 4b/5a) survives as the only document from this phase. These five men drove seven of Šalimahum's donkeys and the goods he had purchased from Aššur to Kaneš. Nūr-Ištar's bill of lading recorded Nūr-Ištar taking one donkey load of textiles. The caravan account (2-Prag I 426) confirms that the shipments of tin were sent according to standard practice: two burdens (šuqlum) of tin slabs totalling 65 minas each were wrapped in šurum textiles and packed on either side of a packsaddle, and sealed for the duration of the trip. ${ }^{17}$ Nūr-Ištar was given 5 minas of tin and additionally some copper for him and his one donkey (1-CCT 4 4b/5a:6-7). The "hand tin" (annak qātim) was used to pay expenses at inns and caravanserais, tolls through cities, and across bridges and ferries, to purchase fodder for the donkeys and feed for himself, sometimes to hire guides or armed escorts, and likely to

16. One of transporters in this caravan cycle, Nūr-Ištar, was referred to as a sāridum, often translated "packer." Another term used much less often was rādi'um (rādi luqūtim, BIN 4 1:19, see also K. R. Veenhof, Aspects, 252), though Nūr-Ištar's activity in this instance was described with the verb radä'um by the representatives (2-Prag I 426:22). The rädi'um seems to be associated more often with armed escorts or as guides. In addition to these two terms, kașsārum designated another transporter, translated “pack master," or "caravan leader." See J. G. Dercksen, Old Assyrian Institutions, PIHANS 98 (Leiden: Nederlands Instituut voor het Nabije Oosten, 2004), 283, and G. Barjamovic, Historical Geography of Anatolia in the Old Assyrian Colony Period, CNI Publications 38 (Copenhagen: Carsten Niebuhr Institute of Ancient Near Eastern Studies, 2011), 15 .

17. For the further breakdown of the tin load into "half-packs" (muttatum), each containing a šuqlum bundle, in turn composed of two packets containing three slabs of tin, each approximately weighing 101/2 minas, wrapped in a šurum textile, see Veenhof and Eidem, Mesopotamia: The Old Assyrian Period, 82. 
pay bribes. ${ }^{18}$ Donkeys took anywhere from two dozen to thirty textiles. Many donkeys laden with tin carried a few textiles on top without severe distress. ${ }^{19}$

\section{Phase Two: Receiving and Selling the Goods}

The moment of the arrival in Kaneš is documented by the long and detailed caravan account drawn up by Làqēpum, Pūšu-kēn, and Ilī-ālum. The copy Pūšu-kēn kept in Kaneš survives (2-Prag I 426). Before selling the goods on credit, the representatives cleared the goods through customs by paying various import duties and settling expenses with the drivers. ${ }^{20}$ Šalim-ahum's representatives first oversaw the paying of import duties and tithes to the palace: an excise duty on tin (nishätum - 4 minas of tin per 130 minas of tin [a donkey load]), and both a tithe (išrătum-one textile in ten), and an excise duty on the textiles (nishătum-one textile in twenty). After the goods were cleared, Šalim-ahum's representatives settled accounts (nikkassī šasäum) with Šalim-ahum's drivers, repaying (apālum) expenses paid in excess of the "hand tin" where necessary. The representatives separated the report on clearing the goods, balancing with the transporters, and selling the goods according to the transporters and their cargo in the following order: 1) son of Erra-idī, 2) Nūr-Ištar and Aššur-muttabbil, and 3) Ah-šalim.

The representatives reported first on Erra-idîs son and his pair of donkeys, though they did not report exact duties paid and had not yet settled accounts with him. However, the report on Erra-idì's son exemplifies how the caravan account provides a good understanding of the cargoes that left Aššur. The cargo of Erra-idìs son lacked 3 minas 52 shekels (mutâū usually translated as "deficiencies"), revealing that while his cargo had been nominally listed as 130 minas for purposes of accounting on the road and at customs in Kaneš, in fact he left Aššur with 126 minas 8 shekels tin. He turned over twenty-seven textiles after customs, but because the representatives did not report duties paid on the textiles, the total number of textiles brought by Erra-idìs son cannot be traced. The donkey carrying textiles could have brought between twenty-four or thirty textiles; the other donkey loaded with tin may have carried some textiles in a top-pack..$^{21}$

Next, the representatives discussed clearance and sale of the goods brought by Aššur-muttabbil and Nūr-Ištar, which passed through customs as a unit (11. 18-45). The representatives accounted precisely for the cleared tin in Aššur-muttabbil's cargo. ${ }^{22}$ Aššur-muttabbil had exceeded his allotted "hand tin" by 7 minas 27 shekels of tin and

18. Because silver was much cheaper in Anatolia, taking silver to Anatolia was wasteful. The copies of treaties between large cities, including Apum, Hुahhum, and Kaneš, as well as one with a small, unknown town, show that palaces and caravanserais along the routes willingly accepted tin instead of silver from those travelling towards Kaneš. Silver-rich merchants travelling back from Anatolia would be assessed in silver. For a treatment of the treaties, see Veenhof and Eidem, Mesopotamia: The Old Assyrian Period, 183-218. For a list of expenses involved in transporting, see Veenhof, Aspects, 248-53; Barjamovic, Historical Geography, 34-51.

19. For a review of textiles in the trade, see C. Michel and K. R. Veenhof, "The Textiles Traded by the Assyrians in Anatolia (19th-18th centuries BC)," in Textile Terminologies in the Ancient Near East and Mediterranean from the Third to the First Millennia BC, ed. C. Michel and M.-L. Nosch, Ancient Textiles Series 8 (Oxford: Oxbow Books, 2010), 210-71.

20. These assessments are normally translated as taxes, e.g., Veenhof and Eidem, Mesopotamia: The Old Assyrian Period, 82-83. I find useful the distinction between taxes, which were assessed on the members of a community, and duties, which were assessed on outsiders. This is not a distinction that is clearly made by the vocabulary of the merchants. Merchants paid nishātum as tax when departing from the city of Aššur, then paid nishătum as duty when arriving in Kaneš. Expenses such as dātum were also used to refer to both tolls on the road and to monies paid into the merchant community itself. In Kaneš the palace assessed nishătum and išrātum duties.

21. The agents state that Erra-idìs son turned twenty-seven textiles over to them after the clearing process. Because twenty of these textiles were sold and the other seven textiles were deposited in Šalim-ahum's account, the original amount before duties and taxes must have been greater. If Erra-idỉs son brought twenty-eight textiles, the excise tax would have been $12 / 5$ textiles. In that case, the palace would have likely taken two textiles and then have been responsible to refund 12 shekels of silver. If there had been twenty-nine textiles, the palace could have taken two textiles and repaid 11 shekels back to Šalim-ahum's agents. However, if the palace also purchased the tithe on the textiles then there would have to have been at least thirty-two textiles for Erra-idỉ's son to have turned over twenty-seven textiles to Šalim-ahum's agents after passing through customs. (Thirty-two textiles would have yielded $13 / 5$ excise and three textiles as tithe; the palace could have taken five textiles and repaid 8 shekels of silver to the agents.)

22. The excise duty on the 130 minas of tin was 4 minas of tin, and there was 4 minas 54 shekels of tin deficient. 
was remunerated by Šalim-ahum's representatives (2-Prag I 426:30-32). ${ }^{23}$ Aššur-muttabbil also brought 5 kutānum textiles atop the tin on his donkey. Those textiles in Aššur-muttabbil's top-pack paid for the tithe and excise duty on Nūr-Ištar's textiles, allowing Nūr-Ištar's 26 "extremely fine" kutānum textiles to clear en bloc. While there is a half textile unaccounted for in the details of paying the nishātum and the išrātum and a textile taken by an Ilabratbāni, it seems likely that Šalim-ahum's strategy was to maximize clearing the "extremely fine" textiles by paying the duties with the other textiles. ${ }^{24}$

Finally, the representatives reported on the three donkeys loaded with tin brought by Ah-šalim (2-Prag I 426:45-55). Though Ah-šalim's cargo was nominally specified as 390 minas of tin, the actual amount was deficient by 3 minas 10 shekels, meaning 386 minas 50 shekels of tin left Aššur. The palace took 21 minas of tin instead of the expected 12 minas for the excise duty. ${ }^{25}$ The representatives did not record their settlement with Ah-šalim, nor did they record the involvement of Amurrum-bāni in the caravan account, though from later records it is clear he accompanied Ah-šalim (5-TC 3 23:40-42). Table 1 summarizes the packaging, transportation, and customs clearance of the goods.

The representatives were to sell the tin and textiles on credit to reliable merchants, be flexible on the length of the credit term, sell the donkeys along with the merchandise, and send a full report (têrtum zakûtum) when all of this was completed (1-CCT 2 4b/5a:11-17). Šalim-ahum's representatives promptly sold most of the goods in three lots as soon as they cleared the merchandise through customs. Each of these three lots consisted of a combination of tin and textiles, and two largely corresponded to the contours of two separate cargoes as they passed customs. The largest, Lot 1, consisted of about 5 talents of tin from the cargo of Ah-šalim and fifty kutànum textiles from an unknown source and was sold on short terms for almost a talent of silver (2-Prag I 426:50-55). Lot 2 derived directly from Erra-idỉs son's cargo, and sold for almost half a talent of silver (2-Prag I 426:11-16). Most of the combined cargo of Aššur-muttabbil and Nūr-Ištar made up Lot 3, selling for just over half a talent of silver (2-Prag I 426:41-44). Though Lots 2 and 3 were both sold on long terms, they fell due at different times as demonstrated in the letters of receipt (6-TC $323 ; 8$-BIN 426$).{ }^{26}$ The three lots in numbered order, together with the fourth lot, sold later, are displayed in table 2.

23. If Aššur-muttabbil were given "hand tin" equal to Nūr-Ištar's at departure, then his average daily expense would have been about 25 shekels of tin per day-higher than average. One transporter in the trade recorded a cost of 61\%4 shekels of tin between Aššur and Qațtara, likely a three days' journey. Had Aššur-muttabbil's donkey died, it would have cost him a mina or two of tin to replace it. Or perhaps Aššur-muttabbil hired an extra donkey to lighten the load through the mountains. Few references to the toll at the Euphrates are available, but one source suggests that the toll for one donkey was 3 or 4 shekels of tin (kt g/k 220, courtesy C. Günbattı); for further discussion, see Barjamovic, Historical Geography, 22.

24. The excise duty on the thirty-one total kutānum textiles (Nur-Ištar's $26+$ Aššur-muttabbil's 5) was 11/2 + 1/20 textiles. The representatives handed over the $1 \frac{1 / 2}{2}$ textiles and repaid the remaining $1 / 20$ with 1 shekel silver, suggesting that the textiles were valued at 20 shekels each. The išrātum was levied at $31 / 30$ textiles and the palace actually purchased three textiles. Ilabrat-bāni took another textile. The total textiles paid out during customs thus adds up to $5 \frac{1}{2}$ textiles, implying an extra one-half textile more than the original cargoes included. As the nishătum and išrātum were expressed rather precisely, it is possible that Ilabrat-bāni only took half of a textile; the brief aside, 1 TÚG iš-tí NIN.ŠUBUR-ba-ni (1. 25), seems the most informal of the accounting statements. Interestingly, Ilabrat-bāni’s taking of a $1 \frac{1}{2}$ textile, mentioned in another series of letters, sparked a heated response from Šalim-ahum: BIN 4 61; TC 2 3; TC 1 26; POAT 7; TC 3 20; CCT 2 3. A case can be made that the present document and those documents refer to the same point in time.

25. Though the expected duty on Ah-šalim's tin cargo is 12 minas, the agents report 21 minas. The reason is unknown. This was not a scribal error for 12 because they subtracted the entire 21 from the total cargo: 390 minas -21 minas -3 minas 10 shekels $\left(m u t t_{a} \bar{u}\right)=365$ minas 50 shekels (2-Prag I 426:45-48). Perhaps each donkey carried 5 textiles in addition to the tin (though not reported), provoking the extra assessment, but the figures don't support such a proposition. Even if the palace had, for some unusual reason, demanded payment in tin for the duty on textiles (unknown elsewhere), the total value of both the excise and tithe duties on textiles Ah-šalim brought would not have matched the discrepancy, 9 minas of tin. The palace would have demanded five textiles for the excise (nishătum) and purchased ten more textiles for the tithe. At 20 shekels of silver each (the likely cash price for textiles, see note directly above), the fifteen kutänum textiles would have been worth 5 minas of silver. Converted to tin at an 8-shekel rate (the price in silver for which the tin from Ah-šalim's tin later sold), the duties on the textiles would have been 40 minas of tin; the nishătum alone would have been 131/3 minas of tin.

26. In this caravan cycle, the length of credit terms influenced prices more than did the quality of goods, and goods sold on short terms were treated as though they were sold for cash. This can be seen by comparing the rates at which tin and textiles were valued at customs and on the market. Among the different lots, the likely standard-grade tin sold at 1/8 its weight in silver on short terms, but sold at 1/7 its weight 
Table 1. Goods shipped and cleared from Šalim-ahum's shipment (2-Prag I 426).

\begin{tabular}{|c|c|c|c|c|c|}
\hline \multicolumn{2}{|l|}{ Transporter } & \multirow{3}{*}{$\begin{array}{l}\text { Donkeys } \\
2\end{array}$} & \multirow{3}{*}{$\begin{array}{l}\text { Tin } \\
126 \mathrm{~m} 8 \check{s}\end{array}$} & \multicolumn{2}{|c|}{ Textiles } \\
\hline & & & & kutānum & šurum \\
\hline \multirow{2}{*}{ Erra-idī’s son } & Original Cargo & & & $28-32$ & 4 \\
\hline & After Customs & $2 \dagger$ & $122 \mathrm{~m} 8 \mathrm{~s}$ & 27 & 4 \\
\hline \multirow{2}{*}{ Nūr-Ištar } & Original Cargo & 1 & & 26 & \\
\hline & After Customs & $1 \dagger$ & & 26 & \\
\hline \multirow{2}{*}{ Aššur-muttabbil } & Original Cargo & 1 & $125 \mathrm{~m} 6 \mathrm{~s}$ & 5 & 4 \\
\hline & After Customs & 1 & $113 \mathrm{~m} 39 \mathrm{~s}$ & 0 & 4 \\
\hline \multirow{2}{*}{ Ah-šalim } & Original Cargo & 3 & $386 \mathrm{~m} 50$ š & & 12 \\
\hline & After Customs & 3 & $365 \mathrm{~m} 50$ š & & 12 \\
\hline \multicolumn{2}{|c|}{ Total Sent from Aššur } & 7 & $638 \mathrm{~m} 4 \check{s}$ & $59-63$ & 20 \\
\hline \multicolumn{2}{|c|}{ Total After Customs } & 4 & $601 \mathrm{~m} 37 \mathrm{~s}$ & 53 & 20 \\
\hline
\end{tabular}

( $\mathrm{m}=$ minas, $\check{s}=$ shekels, $\dagger=$ death of donkey)

Table 2. Lots sold from the shipments arriving in Kaneš as reported in 2-Prag I 426 and 8-BIN 426.

\begin{tabular}{|c|c|c|c|c|c|c|c|c|c|c|c|}
\hline \multicolumn{9}{|c|}{ Composition of Lots and Prices of Each Good } & \multirow[b]{2}{*}{$\begin{array}{c}\text { Total } \\
\text { Reported } \\
\text { Price/Claim } \\
\text { in Silver }\end{array}$} & \multirow[b]{2}{*}{$\begin{array}{l}\text { Term } \\
\text { Length }\end{array}$} & \multirow[b]{2}{*}{$\begin{array}{c}\text { Original } \\
\text { Transporters }\end{array}$} \\
\hline to & 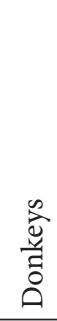 & 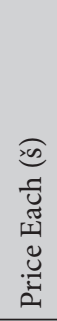 & $\Xi$ & 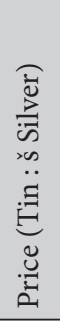 & 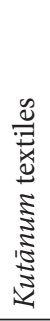 & 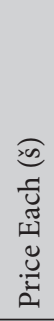 & 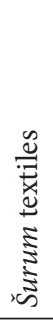 & 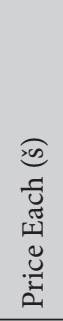 & & & \\
\hline 1 & - & & $304 \mathrm{~m} 40$ š & 8 & 50 & 20 & 12 & $0^{* *}$ & $54 \mathrm{~m} 45 \check{s}$ & Short & Ah-šalim \\
\hline 2 & - & & $122 \mathrm{~m} 8 \mathrm{~s}$ & 7 & 20 & 30 & 4 & 15 & $28 \mathrm{~m} 27 \check{s}$ & Long & Erra-idī’s son \\
\hline 3 & 1 & 30 & $124 \mathrm{~m} 39 \check{s}$ & 7 & 26 & 30 & - & & $31 \mathrm{~m} \mathrm{1} 18^{1} / 2 \check{s}$ & Long & $\begin{array}{l}\text { Aššur- } \\
\text { muttabbil \& } \\
\text { Nür-Ištar }\end{array}$ \\
\hline 4 & - & & $61 \mathrm{~m} 10$ š & $8^{3 *}$ & - & & - & & $12 \mathrm{~m} \mathrm{3} 35^{2} / 3 \mathrm{~s}$ & Long & Aḩ-šalim \\
\hline
\end{tabular}

$(\mathrm{m}=$ minas, $\check{s}=$ shekels. $)$

* See note to 8-BIN 4 26:41 above.

${ }^{*}$ The 12 surum textiles in Lot 1 are priced at zero because they were bundled in with the tin (2-Prag I 426:50-52). The price of the lot suggests that the šurum textiles that were taken were those wrapping the tin. 
All indications are that the representatives wrote the caravan account and its copy (2-Prag I 426) soon after the drivers arrived in town, the three sales having been transacted quickly. At the writing of the account, they had yet to settle with some of the drivers and they had yet to sell roughly a talent of tin (61 minas 10 shekels) left from Ah-šalim's cargo. This last talent of tin, Lot 4, was sold later, as acknowledged by Šalim-ahum (6-TC 3 23:4-8, 8-BIN 4 26:40-44). When all his goods had been sold on credit, Šalim-ahum's claims totaled slightly more than two talents of silver (127 minas 5 5/6 shekels). That the representatives wrote this caravan account before they sold all the merchandise and finished with the drivers suggests that Šalim-ahum expected his representatives to provide information in a timely manner.

Despite the density of detail in the caravan account, our information is still fragmentary. In the surviving copy, the representatives did not include the precise due dates of the claims. As a result, we cannot express the length of each claim's term in weeks or months as we can in other instances. ${ }^{27}$ However, Šalim-ahum knew which claims would fall due first, second, third, and fourth with far more nuance than the caravan account's "short terms" and "long terms" communicated; he reminded his representatives of their progressive maturation in later letters (6-TC $323 ; 8$-BIN 4 26). Perhaps the copy of the caravan account sent to Šalim-ahum did express the precise term lengths. He might also have had this information because the representatives also sent copies of the debt notes from the credit sales. Note that a different caravan account (BIN 4 61) from a different caravan cycle, written by Lā-qēpum and Ilī-ālum to Šalim-ahum, expressed the number of weeks given for credit terms.

\section{Phase Three: Collecting the Claims}

During the remainder of the caravan cycle, letters and shipments ebbed and flowed as Šalim-ahum's claims fell due, his representatives collected silver and sent it to him, and he acknowledged receipt. Before the Claim on Lot 1 fell due, Šalim-ahum had sent two different letters to the representatives. The first letter (3-POAT 19) was written before he had received the caravan account (2-Prag I 426). In it Šalim-ahum told his representatives, "my tin and textiles should not be stocked up" (3-POAT 19:3-5). Šalim-ahum also reminded the representatives to report on the sale of goods when further transporters arrived (11. 10-20). Subsequently Šalim-ahum wrote about contemporary matters in Durhumit, where three parties owed three debts (1l. 21-27). These claims were mentioned several more times in Šalim-ahum's letters during this caravan cycle (4-TC 1 14:23-30; 6-TC 3 23:25-27; 8-BIN 4 26:13-17): Aššur-šamšsiss sons owed a combined total of 10 minas 10 shekels of silver. Hinnaya was responsible for a debt of 21 minas 17 shekels of silver, which he had extended on credit on behalf of Šalim-ahum (4-TC 1 14:27-30). Amur-Ištar owed 5 minas of silver, for which Hinnaya was also responsible.

\footnotetext{
on long terms. Surprisingly, the "extremely fine" textiles sold for the lowest price of all textiles in the caravan cycle. While textiles sold on long terms garnered 30 shekels each, Nür-Ištar's "extremely fine" textiles sold for only 20 shekels each-presumably because they were sold on short terms. The textiles fetching 30 shekels may also have been "extremely fine," but they were not described as such in the caravan account as were Nür-Ištar's textiles. How quickly the "extremely fine" textiles would be paid for was more consequential than that they seemed to be worth more (in the present) than the other textiles in the shipment. Šalim-ahum had paired Nür-Ištar's "extremely fine" textiles with the five textiles brought by Aššur-muttabbil so that the fine textiles would clear customs together (as reviewed above); but in the end the "extremely fine" textiles were valued the same as Aššur-muttabbil's five textiles. When the textiles cleared customs, the cash rate the palace paid for textiles-20 shekels-was the same rate the "extremely fine" textiles fetched when sold on short terms. This arrangement of affairs suggests not only that there were two basic classes of rates: those sold on short terms and on long terms; but also that the rate for those sold on short terms, at least as discussed by Šalim-ahum and his representatives, was "same as cash" and applied to anything paid within about two months. At least in this example, the equivalence between the rate at which the balance was repaid to the palace in customs and the price of the textiles sold on short terms supports the proposition that the palace valued goods in customs according to the market price. The variation of $10,15,20$, and $26^{2} / 3$ shekels per textiles paid at customs is listed in K. R. Veenhof, "Silver and Credit in Old Assyrian Trade," in Trade and Finance in Ancient Mesopotamia: Proceedings of the First MOS Symposium, ed. J. G. Dercksen, PIHANS 84 (Leiden: Nederlands Instituut voor het Nabije Oosten, 1999), 83. See also Veenhof, Aspects, 84. Cf. Larsen, Old Assyrian Caravan Procedures, 159.

27. For a discussion of the length of the hamuštum as the seven-day week, see K. R. Veenhof, "The Old Assyrian Hamuštum Period: A Seven-Day Week," JEOL 34 (1996) 5-26.
} 
Shortly after writing 3-POAT 19, Šalim-ahum sent another letter to the representatives (4-TC 1 14). Again Šalim-ahum discussed the debts arising in Durhumit (11. 23-30). The subject matter of the two letters is so similar that they could almost be mistaken for variant copies. However there is a clear progression of events between the two letters, and Šalim-ahum's intent changes between the two. To begin with, in 3-POAT 19, Šalim-ahum addressed only Lā-qēpum and Pūšu-kēn, the same two persons he addressed in Nūr-Ištar's bill of lading (1-CCT 2 4b/5a:1-3). Later in 4-TC 1 14, he also addressed Ilī-ālum after learning from the caravan account (2-Prag I 426) that Ilī-ālum was helping to manage Šalim-ahum's affairs in Kaneš. The passage of time between the two letters is also marked by the development of one of the claims. In the first letter, Šalim-ahum responded to a need for clarification about the claims related to Aššur-šamšìs sons and Hुinnaya, described the claims precisely, and instructed the representatives saying: "have all this paid and send it to me at the first opportunity" (3-POAT 19:25-27). Later Šalim-ahum's more terse language presupposed his previous comments on the matter: "... their terms are full. Let your report come" (4-TC 1 14:30-32). The movements of the transporters between the two letters also corroborate the forward progress of time. When Šalim-ahum wrote 3-POAT 19, he asked Lā-qēpum and Pūšu-kēn to send a report as to when Dān-Aššur was to arrive in Kaneš. When he later sent 4-TC 1 14, Šalim-ahum assumed that Dān-Aššur would have arrived by the time his letter did and asked the representatives to send Dān-Aššur home. When Šalim-ahum later wrote 8-BIN 4 26, he acknowledged that Dān-Aššur had returned to Aššur.

By the time they received Šalim-ahum's later letter (4-TC 114$)$, his representatives had likely already begun to collect some of the silver Šalim-ahum was demanding. They entrusted nearly 53 minas of silver and a letter to two transporters (Ennam-Aššur son of Šū-Aššur, Aššur-mālik son of Erraya), keeping a memo of the amounts entrusted and witnesses present (5-VS 26 130). ${ }^{28}$ The amount of silver sent included silver for both the excise tax (nishātum), paid at arrival in Aššrur at 2 percent, and transport tariff (šadduātum), paid to the transporters at a rate of 1:60. ${ }^{29}$ Because the surviving memo (5-VS 26 130) is damaged, it is difficult to determine how much silver was collected from whom in Anatolia. Some silver owed by the sons of Aššur-šamšĩ was paid through Ennam-Aššur son of Šü-Enlil (5-VS 26 130:3'-5'). At least 332/3 minas were collected from someone simply designated as "Šalimahum's merchant." The latter must have been the buyer of Lot 1, though he had only paid about two-thirds of his debt. To total the 53 minas of silver sent, the representatives would have to have collected all of Aššur-šamšrss sons' silver (10 minas 10 shekels), plus ten more minas from others at Durhumit (Hinnaya or Amur-Ištar). However, if Šalim-ahum's later letters are accurate, none of the persons from Durhumit paid in full, since he mentioned later all as owing something (8-BIN 4 26:10-17).

When these first packets of silver arrived in Aššur, Šalim-ahum wrote a letter of receipt (6-TC 3 23). In it, Šalim-ahum's accounting essentially credited all the silver he received to the Claim on Lot 1 (11. 9-14), despite the representatives having received some silver from Aššur-šamšìs sons (5-VS 26 130:3'-5'). At the same time, Šalimahum also noted that the Claim on Lot 2 was maturing. Though sold on long terms, this claim was falling due relatively soon after the first claim, which was sold on short terms-soon enough for Šalim-ahum to assume the matter pertinent by the time his letter arrived in Kaneš. This could have been as soon as a month after the Claim on Lot 1 was collected, and probably not more than three months. In the last section of the letter Šalim-ahum noted that the be ulatum loans of some of the transporters, including Aššur-muttabbil and Ah-šalim, were coming due (6-TC 3 23:36-41).

Once again, when the representatives received Šalim-ahum's letter (6-TC 323$)$, they were likely already involved in collecting the maturing Claim on Lot 2 . Again the representatives collected another $1 \frac{1 / 2}{2}$ talents of silver and sent the silver and a letter to Šalim-ahum, keeping a copy of the letter for themselves (7-CCT 5 50b). Like the memo (5-VS 26 130), this copy is quite damaged, but the preserved parts discuss the silver shipped previously

28. Though the actions described in the document were undertaken on behalf of Šalim-ahum, it was not addressed to him, as they describe his buyer as "Šalim-ahum's merchant," and they describe the transport of the silver without the dative pronominal suffix, i.e., ubil instead of ublakkum.

29. For discussion of the transport tariff, see Dercksen, Old Assyrian Institutions, 156-63. 
(11. $\left.2^{\prime}-9^{\prime}\right)$. The copy then describes another shipment of silver, which, by comparison with the next letter (8-BIN $426)$, can be identified as the silver brought by Dān-Aššur (1l. 10-14). From the next letter we also know that two others, Kurub-Ištar and Ilī-ālum (the same Ilī-ālum who until that point had been representing Šalim-ahum along with Pūšu-kēn and Lā-qēpum), travelled with Dān-Aššur, each bringing a portion of the 11/2 talents of silver received by Šalim-ahum (8-BIN 4 26:24-30).

When the second shipment of silver arrived in Ǎšur, Šalim-ahum again wrote a letter of receipt (8-BIN 4 26). This time, Šalim-ahum listed all the claims in the previous letter of receipt (11. 18-23) in addition to claims that had just matured (1l. 24-30). Then he made an intermediate accounting: from the nearly 150 minas of silver in claims that were past due, Šalim-ahum cited 30 minas still not collected (8-BIN 4 26:31-34). After making intermediate accounts with his representatives, Šalim-ahum then noted that the Claims on Lots 3 and 4 were both maturing soon, a fact he likely knew from the debt notes or their copies he had likely received earlier (1l. 40-48). He again stressed to the representatives to collect the silver and not to accept promises of interest paid in lieu of the principal amounts (11. 35-40).

After 8-BIN 426 there is no later documentation on this caravan cycle. It is impossible to know whether Šalimahum received the balance of his last two claims as smoothly as he appears to have received those on his first two. Even if he did not recoup those monies in the short run, he had already netted roughly two and half talents (152 minas) of silver, though as much as 36 minas of silver from this amount derived from the claims at Durhumit. He had likely spent roughly two talents (ca. 110 minas) on goods at the beginning of the caravan cycle. ${ }^{30}$

\section{The Documentary Topography of Šalim-ahum's Caravan Cycle: Šalim-ahum's Accuracy}

Less than a third, perhaps less than a fourth, of the original documentation created during Šalim-ahum's caravan cycle survives, ${ }^{31}$ yet no other single Old Assyrian caravan cycle is so well documented. Once it becomes clear that these eight documents form the remnants of an epistolary conversation between Šalim-ahum and his representatives, the way in which the same assets are described during the epistolary conversation provokes questions about how accurate Old Assyrian merchants were in their communications. Thousands of Old Assyrian documents refer to assets held, owned, and sold. From the many detailed descriptions and occasional miserly comments, Assyrian merchants seem to have employed and expected a fastidious level of accuracy. In turn, we often draw on this sense of precision when judging whether two documents are connected or not. ${ }^{32}$ When considering

30. Šalim-ahum never reported to his agents how much he initially paid for his goods. The estimated amount is attained by combining average prices in silver for the goods and services involved: tin (4 shekels of silver for a mina of tin), textiles (kutānum, 5 shekels of silver; very fine kutānum, 9 shekels of silver; šürum, 2 shekels of silver), donkeys ( 30 shekels of silver each), tack and fodder (5 shekels), "hand tin" (40 shekels of silver), exit tax per donkey (wasitum, 2 shekels of silver), and payment to transporters (15 shekels of silver).

31. At the time Šalim-ahum bought and shipped the goods, he drew up at least a dozen documents, including transport contracts, bills of lading, a letter of notification, and memos for his own records. When the goods arrived in Kaneš, the representatives created at least another eight documents: three debt notes with copies (or a memorandum for Šalim-ahum), the caravan account and its copy, and perhaps another memo for their own records. It is also not unlikely that the transporters on the journey sent a few letters. Afterward, when the representatives collected funds, they made memos like 5-VS 26130 and when they sent letters they kept copies like 2-Prag I 426 and 7-CCT 5 50b. Šalim-ahum did not hesitate to send four letters during the caravan cycle, and he doubtless sent other letters as well. All told the total documents including memos would have easily passed thirty, if not three dozen, tablets.

32. Such skepticism would have hindered a detour in clarifying the difference between Kültepe Level II and Level Ib in an earlier phase of scholarship on the Old Assyrian trade. When the chronology of the Boğazköy and Alişar Old Assyrian texts was still unclear, J. Lewy argued that the Old Assyrian texts found in Alişar and Boğazköy belonged in the period of Kültepe Level II (rather than Level Ib) on the strength of, among other things, the same name mentioned in texts from the three different locations: J. Lewy, "Apropos of a Recent Study in Old Assyrian Chronology," Or 26 (1957) 16-20. Kemal Balkan had correctly argued earlier that the texts from Alişar and Boğazköy were contemporary with Level Ib, appealing to orthographic and linguistic evidence; see K. Balkan, Observations on the Chronological Problems of the Kärum Kanǐs, Türk Tarih Kurumu Yayınları 7/28 (Ankara: Türk Tarih Kurumu, 1955). 
Table 3. Variation in Expressed Amounts of Šalim-ahum's Assets in Select Texts.

\begin{tabular}{|c|c|c|c|c|c|c|c|}
\hline & 2-Prag I 426 & 3-POAT 19 & 4-TC 114 & 5-VS 26130 & 6-TC 323 & 7-CCT 5 50b & 8-BIN 426 \\
\hline Claim on Lot 1 & $54 \mathrm{~m} 45 \mathrm{~s}$ & & & & $54 \mathrm{~m} 45 \mathrm{~s}$ & & $54 \mathrm{~m} 451 / 2 \check{s}$ \\
\hline Claim on Lot 2 & $28 \mathrm{~m} 27 \mathrm{~s}$ & & & & (broken) & & $28 \mathrm{~m} 27 \check{s}$ \\
\hline Claim on Lot 3 & $31 \mathrm{~m} 181 / 2 \mathrm{~s}$ & & & & & & $31 \mathrm{~m} 18^{1 / 2 s ̌}$ \\
\hline Claim on Lot 4 & & & & & $12 \mathrm{~m} 35^{2} / 3$ s & & $12 \mathrm{~m} 35^{2} / 3$ s \\
\hline Silver Packet $1^{\star}$ & & & & $31 \mathrm{~m} 45 \mathrm{~s}$ & $31 \mathrm{~m} 30 \mathrm{~s}$ & $31 \mathrm{~m} 45 \mathrm{~s}$ & $31 \mathrm{~m} 45 \mathrm{~s}$ \\
\hline Silver Packet $2^{\star}$ & & & & $21 \mathrm{~m} 10 \mathrm{~s}$ & $21 \mathrm{~m} 10 \mathrm{~s}$ & $21 \mathrm{~m} 10 \mathrm{~s}$ & $21 \mathrm{~m} 10 \mathrm{~s}$ \\
\hline Silver Packet 3 & & & & & & $(31 \mathrm{~m} 45 \mathrm{~s})$ & $31 \mathrm{~m} 451 / 2 \check{s}$ \\
\hline Additional Silver & & & & & & $2 \mathrm{~m}$ & $2 \mathrm{~m}$ \\
\hline šep Pūšu-kēn & & & & & $58 \mathrm{~m} 181 / 2 \check{s}$ & & $58 \mathrm{~m} 181 / 2 \check{s}$ \\
\hline$m e r ' \bar{e}$ Aššur-šamšì & & {$[10] \mathrm{m} 10 \mathrm{~s}$} & $10 \frac{1}{2} \mathrm{~m}$ & & (broken) & $>$ & $211 / \mathrm{m}$ \\
\hline Hinnaya & & $(21 \mathrm{~m} \mathrm{17š)}$ & $21 \mathrm{~m}$ & & $21 \mathrm{~m}[\mathrm{x}]$ & & $31 \frac{1}{2} 2 \mathrm{~m}$ \\
\hline Amur-Ištar & & $5 \mathrm{~m}$ & & & (broken) & & $5 \mathrm{~m}$ \\
\hline
\end{tabular}

$(\mathrm{m}=$ minas, $\check{s}=$ shekels $)$

${ }^{*}$ Cited figures for both silver packets include the duties and tariffs paid on the silver described in those references.

whether or not to connect two caravan documents, M. T. Larsen explained, "We cannot know whether another shipment of exactly the same size, involving the same persons, etc. has been recorded on other tablets lying in the yet undug houses of Kültepe or in museums or perhaps irretrievably lost." ${ }^{33}$ But in the epistolary conversation from this caravan cycle, Šalim-ahum was less precise than we might have expected and less precise than a sense of fastidious accuracy suggests-and his variations are not such that they can be explained by appeal to errors in copying cuneiform numbers. ${ }^{34}$ At the same time, at least three different contexts can be differentiated that serve in part to explain when Šalim-ahum was precise, and when more approximate descriptions were permissible.

Table 3 lists figures for Šalim-ahum's assets reported more than once in the caravan-cycle documentation (figures entirely reconstructed are omitted). The columns listing documents are ordered chronologically, with those documents composed by Šalim-ahum shaded in gray. The row entries are divided into three sections, with references to claims in the top section, references to actual silver received in the middle section, and references to other contemporary debts owed to Šalim-ahum in the bottom section.

There is a range of discrepancies both among Šalim-ahum's own descriptions of his assets and between his reports and those of his representatives. Many figures match exactly, such as the amount for Silver Packet 2: consistently 21 minas 10 shekels across four documents composed both by Šalim-ahum and the representatives. Some discrepancies are insignificant: Šalim-ahum listed Silver Packet 1 as $31 \frac{1}{2}$ minas of silver plus transport tariff (6-TC 3 23:10-11), but in the second letter of receipt he recorded 31 minas 15 shekels of silver plus $1 / 2$ mina transport tariff (8-BIN 4 26:18-19). But some discrepancies are instructive: Šalim-ahum precisely described the debt owed by Aššur-šamšiss sons (10 minas 10 shekels) and, by subtraction, the debt of Hinnaya (21 minas 17 shekels) in the first letter dealing with the topic (3-POAT 19:21-24), but varied in his precision when describing the assets thereafter. In one place, he described the debt of Aššur-šamšìs sons as 101/2 minas and Hinnaya’s debt as 21 minas (4-TC 1 14:23-29); still later the total of the two debts was approximated as $31 \frac{112}{2}$ minas (8-BIN 4 26:10-12). One discrepancy suggests that more detail does not necessarily mean more accuracy: the representatives cited the Claim

33. Larsen, Old Assyrian Caravan Procedures, 19-20.

34. Most of Šalim-ahum's errors involve the presence or omission of a $1 / 2$ shekel, the decision to render a figure only in minas and half minas (as opposed to minas and shekels), or some other variation that does not lend itself to missing a vertical wedge in a cuneiform number. The author collated 8-BIN 4 26, consulted the photos of 3-POAT 19 and 5-VS 26130 (http://www.cdli.ucla.edu), and appealed to M. T. Larsen's collations for the tablets at the British Museum (1-CCT 2 4b/5a; 7-CCT 5 50b). 
on Lot 1 as 54 minas 45 shekels in their copy of the caravan account (2-Prag I 426:54), and Šalim-ahum cited the same amount in one document (6-TC 3 23:9), but later credited himself 54 minas 45 and 1/2 shekels (8-BIN 4 26:3). Given the consensus between Šalim-ahum's earlier amount and the copy of the representatives' document, which is closest to the event, it seems like Šalim-ahum was inflating his claim.

When specific aspects of the caravan cycle are described differently in various documents, we gain valuable information. For example, it is clear that a transporter named Aššur-mālik in one letter (6-TC 3 23:12-13) was the same person referred to as Erraya's son in another missive (8-BIN 4 26:21-23), and not one of the more than one hundred other men named Aššur-mālik attested in the Old Assyrian corpus. But when amounts of assets diverge, determining which figures were valid becomes difficult. Were there conditions that prompted one level of precision over another? It seems Šalim-ahum intuitively matched his level of accuracy to at least three different contexts, which I will style conversational, legal, and accounting.

The most consistent divergences in figure amounts seem to come in documentary contexts that could be described as conversational. In many instances, Šalim-ahum mentioned assets in an ongoing discussion and needed only to distinguish sufficiently the asset from a finite number of other active assets under the care of his representatives-not a terribly difficult task when constantly exchanging letters. As already mentioned, when we first pick up the debts of Aššur-šamšìs sons and Hुinnaya originating from Durhumit in the epistolary conversation, Šalim-ahum was taking pains to clarify the exact amounts (10 minas 10 shekels, 21 minas 17 shekels, 3-POAT 19:21-24). Later, when he referred to these same claims, he cited approximated or combined figures $\left(10 \frac{1}{2} \mathrm{minas}\right.$, 21 minas, and combined as $31^{1 / 2}$ minas) sufficient for recognition by the representatives-and by ourselves. In this context, Šalim-ahum seemed to gravitate to full- and half-mina amounts. In the broader contexts of Old Assyrian communication, it was common for merchants to use approximations, such as when quantifying their tin on the road in terms of "talents," approximating the 65 mina load of the šuqlum packs. Šalim-ahum certainly did (TC 1 26:14-15). When the amounts were hypothetical, such as in requests, approximate numbers were often used. When Šalim-ahum asked Pūšu-kēn to send silver from Šalim-ahum’s purse in Kaneš on other occasions, he asked for hypothetical amounts, like 20 minas of silver (AKT 3 72:4-6; TC 2 1:22-24) or 30 minas of silver (KTS 1 42d:14-16, 32-33; TC 2 1:14-16). According to Šalim-ahum's letters, such approximations were acceptable when discussing concrete assets as well.

In contrast to conversational contexts, Šalim-ahum obviously needed to be precise in documents with legal force. Only one document from this caravan cycle fits this category. When Šalim-ahum drew up Nür-Ištar's bill of lading in Aššur (1-CCT 2 4b-5a), both Šalim-ahum as the owner and Nür-Ištar as the driver would have checked that the stated amount of cargo was accurate, as the recorded figures became legally binding. The other bills of lading, any transport contracts, and the debt notes drawn up by Šalim-ahum's representatives and the buyers (none of which survive) would also have fallen into this category. We should expect figures in legal documents to reflect the most binding description of assets, and when matching together two legal documents, there is the expectation that figures would match exactly or betray a rearrangement of circumstances in the interim between their creation.

Between conversational and legal communications, there existed communications between principals and agents where accuracy was more meaningful but apparently not legally binding. Šalim-ahum needed to make intermediate accountings with his representatives, separated from him by the long distance between Aššur and Anatolia. Šalim-ahum's communications in this context of accounting exhibited formal characteristics. The format of two letters of receipt sent by Šalim-ahum (6-TC $323 ; 8$-BIN 4 26) both follow similar patterns as highlighted in table 4. In both letters, Šalim-ahum listed (1) claims due (or past due), followed by (2) money received towards those claims; he then listed (3) claims coming due. In both letters, Šalim-ahum included (4) instructions to collect the principal quickly and (5) additional comments as necessary. The progression of sections reflects both a systematic approach to the accounting and a temporal development: first the previous state of the caravan cycle is discussed (those debts that have come due), then the current state (the silver received towards the claims due and the balance due), and finally, instructions pertinent to the time the letter would arrive at its destination (collecting the balance of claims due and those claims coming due). The two letters of receipt Šalim-ahum wrote could be 
Table 4. Comparison of the Contents of 6-TC 323 and 8-BIN 426.

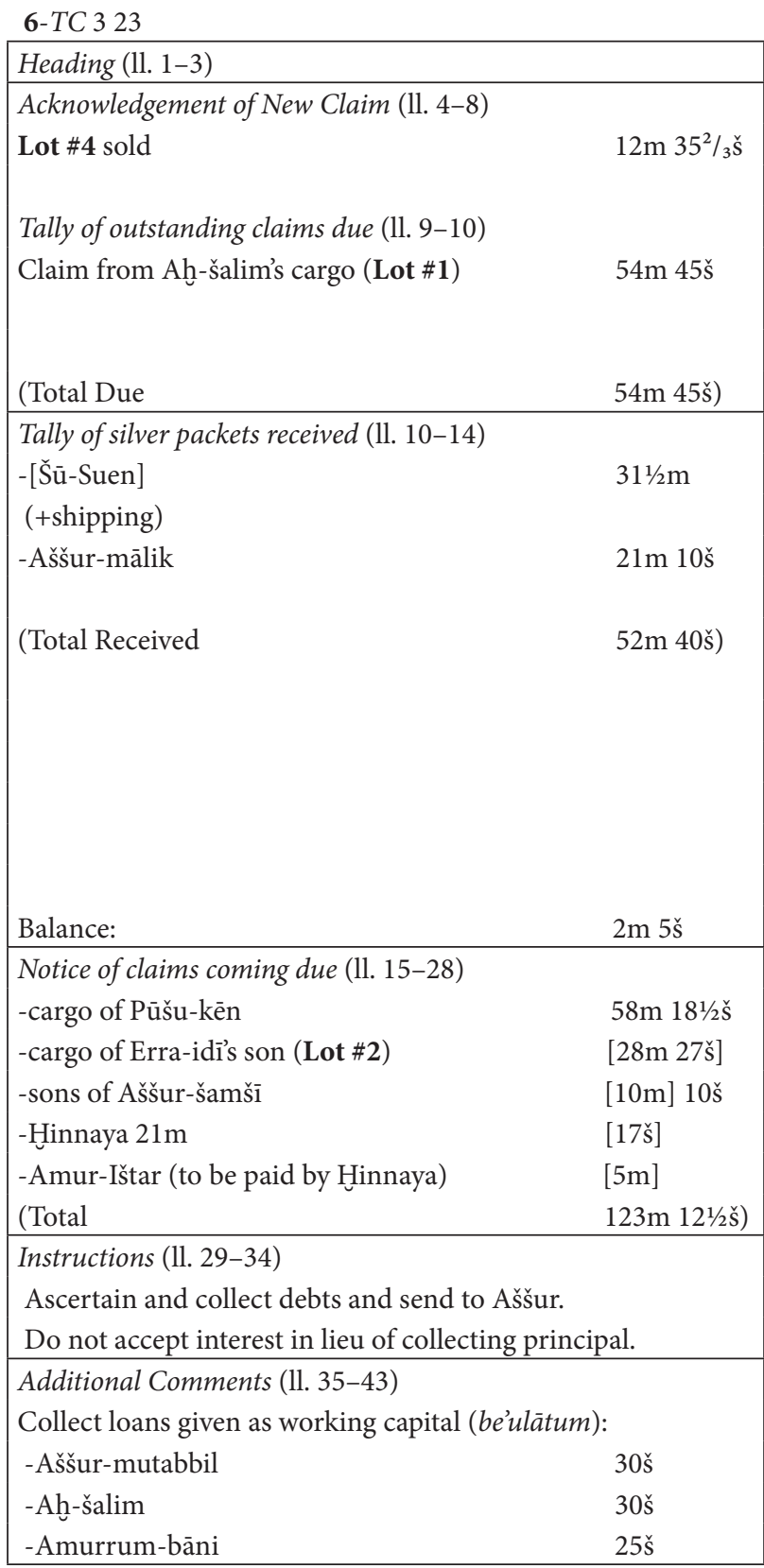

8-BIN 426

Heading (1l. 1-3)

Tally of outstanding claims due (1l. 3-17)

-cargo of Ah-šalim (Lot \#1) 54m 451/2š

-cargo of Pūšu-kēn $\quad 58 \mathrm{~m} \mathrm{18} 1 \frac{1}{2} \mathrm{~s}$

-Lulu s. Zukuhum (Lot \#2) 28m 27š

-Aššur-šamší, Huinnaya $\quad 31 \frac{112 \mathrm{~m}}{2}$

-Amur-Ištar $5 \mathrm{~m}$

Total Due $178 \mathrm{~m} 1 \check{\text { š }}$

Tally of silver packets received (1l. 18-34)

-Šū-Suen w/ DUMU Šū-Aššur $\quad 31 \mathrm{~m} 15 \check{s}$

shipping 30 š

-Erraya’s son 20m 50 š

shipping 20š

-Dān-Aššur $\quad 31 \mathrm{~m} 15^{1 / 2} 2 \check{s}^{2}$

shipping 30 š

separately $2 \mathrm{~m}$

-Ilì-ālum $\quad 41 \mathrm{~m} 40$ š

Shipping 40 š

-Kurub-Ištar $\quad 18 \mathrm{~m} 18$ š

Total (Received) $\quad 147 \mathrm{~m} 18$ š

Balance: $\quad 30 \mathrm{~m} 23$ š

Instructions (1l. 35-40)

Don't accept interest in lieu of collecting principal.

Write to Hinnaya to send silver.

Notice of Claims coming due (1l. 40-48)

-Ah-šalim (Lot \#4) $\quad 12 \mathrm{~m} \mathrm{35} 2 / 3$ š

-Aššur-mutabbil \& Nūr-Ištar (Lot \#3) $\quad 31 \mathrm{~m} \mathrm{18} 1 / 2$ š

(Total $43 \mathrm{~m} 541{ }_{6}{ }_{6} \check{\text { s}}$ )

Additional Comments (1l. 48-51)

Remark regarding documentation.

$(\mathrm{m}=$ minas, $\check{s}=$ shekels $)$

termed intermediate accounts, and potentially we might add this designation as another "Standard Text" alongside the transport-contract, notifying message, and caravan accounts. ${ }^{35}$

The formal characteristics of these two intermediate accounts suggest a pragmatic and methodical accounting. Again, connections between documents reveal information: Lulu son of Zukuhum's debt in the second interme-

35. See Larsen, Old Assyrian Caravan Procedures, 15-43. 
diate account (8-BIN 4 26:8-9) matches exactly the Claim on Lot 2 from the caravan account (2-Prag I 426:14), revealing Lulu as the buyer of Lot 2. However, several of Šalim-ahum's accuracy errors occured in this context, and most are slight or subtle. In the first intermediate account, Šalim-ahum made one deviation against the caravan account, approximating silver received but ignoring the transport tariff (his cost), thus inflating the balance outstanding for his representatives by 15 shekels (6-TC 3 23:10-14). In the second intermediate account (8-BIN 4 26), Šalim-ahum made two errors. He inflated the Claim on Lot 1 by $1 / 2$ shekel (ll. 3-6), and when he listed two of the Durhumit debts as one entry (11. 10-15), he inflated their total by three shekels over the total expressed in an earlier letter (3-POAT 19:21-27). In the context of making intermediate accounts, Šalim-ahum was more precise than in a conversational context, but slightly less accurate than what we might expect in legal frameworks.

The documents from Šalim-ahum's caravan cycle show that Old Assyrian merchants' attitudes toward accuracy could be nuanced. This has implications for pursuing reconstructions of activity across documents. We should still demand a higher threshold of accuracy in the transporting phase of trade where the regularity of the donkey-load and the taxation system dictated that most goods were transported, or at least booked, in packages of nominally the same size and where many documents had legal force. Likewise, in debt notes and other documents with legal force small differences in descriptions are more consequential. However, Šalim-ahum's differing levels of precision in differing contexts suggests that in other phases of the trade and in other documentary contexts, similar descriptions of assets-even when not described precisely the same-may refer to the same assets. Lots sold and claims on lots were less standardized in size and amount, and at least some merchants felt free to be less precise in their communication. When pursuing reconstructions of Old Assyrian documentation, context-and perhaps the disposition of individual authors-can affect the threshold of accuracy one can expect when considering connections between documents. But differences in accuracy can also be read to betray other phenomena, including the social distance between individuals. I will follow this thread further when discussing Šalim-ahum’s representatives below.

\section{Charting the Social Topography of Šalim-ahum's Caravan Cycle: Transporters, Buyers, Representatives}

If Šalim-ahum's varying descriptions of assets highlights one dimension of Old Assyrian communication, his interaction with the range of participants in his caravan cycle also brings into focus other aspects of his mercantile activities. It seems Šalim-ahum needed a reasonably large pool of persons to draw on for different services in order to participate as a wholesale dealer in the trade, but that few of these persons needed to be tied to him in a durable way. The various persons involved in the caravan cycle can be parsed into three different functional groups: (1) those who transported his goods, (2) those who purchased his goods, and (3) those who represented his interests in Anatolia. A number of patterns emerge in Šalim-ahum's epistolary conversation that suggests he conceived of most of these persons as outside his sphere of liability in one way or another. Šalim-ahum made use of a range of drivers because the trade demanded flexibility in finding people to fill that role. But aside from his son, none of these drivers can be confidently established as his durable employees. Šalim-ahum also showed little interest in the identity of "his" buyers, who bought his goods in Anatolia, revealing a social distance between the two parties and suggesting that linguistic markers, like possessives, cannot always be interpreted as markers of social or organizational closeness. Finally, Šalim-ahum seemed to subtly shift small amounts of liability onto his several representatives in Anatolia through his intermediate accounts, suggesting he was only secondarily interested in their short-term financial welfare. The following three sections deal with each of these groups.

\section{Šalim-ahum's Transporters: Employees or Transport for Hire?}

Those who transported Šalim-ahum's goods formed an important part of Šalim-ahum's caravan cycle. No fewer than sixteen different persons were involved in transporting goods for him as mentioned in the documentation 
Table 5. List of Transporters Involved in Šalim-ahum's Caravan Cycle.

\author{
Ah-šalim \\ Amurrum-bāni s. Kurub-Ištar \\ Aššur-mālik s. Erraya \\ Aššur-mālik s. Luzina \\ Aššur-muttabbil s. Šù-Anum \\ Dān-Aššur s. Šalim-ahum \\ Ennam-Aššur s. Šalim-ahum \\ Ennam-Aššur s. Šū-Aššur \\ s. Erra-idī \\ Ilī-ālum \\ Kurub-Ištar \\ Lā-qēpum \\ Nūr-Ištar s. Idī-Ištar \\ Pūšu-kēn \\ s. Šū-Enlil \\ Šū-Suen
}

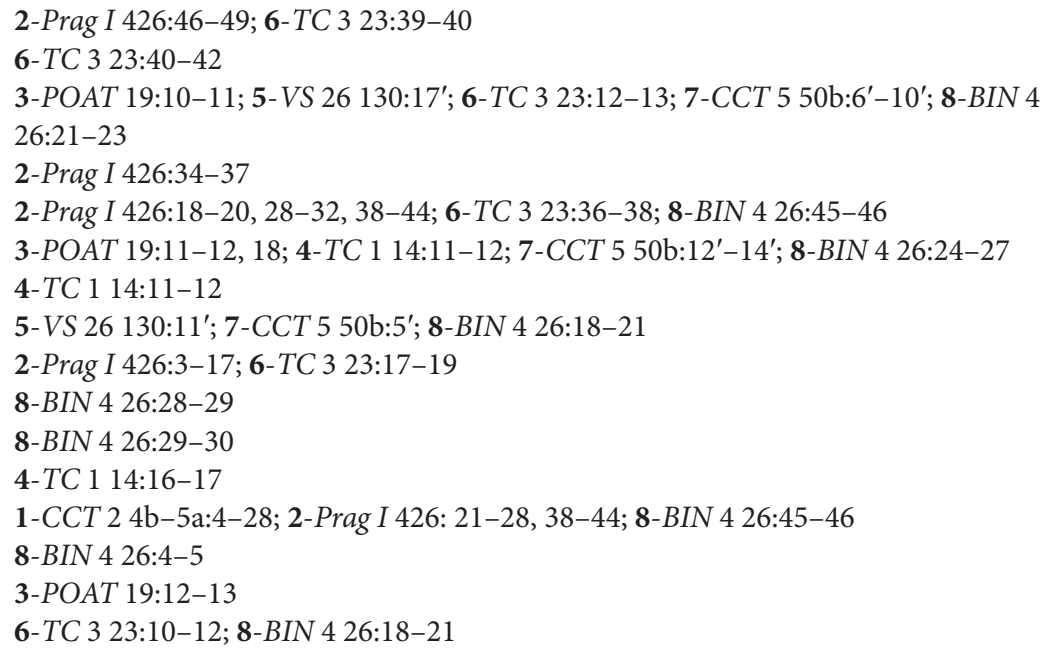

from this caravan cycle. Many drivers only made a single one-way trip for Šalim-ahum during this period. All three of his representatives also transported goods. But it is only occasionally clear whether or not some drivers were really part of Šalim-ahum's durable commercial network. Though Šalim-ahum likely met each of these transporters personally, their social connection to him is difficult to configure.

The number of Šalim-ahum's transporters during the period of this caravan cycle is surprisingly broad, an observation underscored by noting that two of the entries in table 5 that could be the same person in fact are two different persons. It is onomastically possible that Aššur-mālik son of Errāya could have been the same person as the one called the son of Erra-idi, but the activities of the two overlapped in ways that distinguishes them as separate persons. ${ }^{36}$

From the evidence relating to this caravan cycle, only two transporters besides Šalim-ahum's representatives might have been working exclusively for him. Both Aššur-mālik son of Errāya and Dān-Aššur, Šalim-ahum’s son, brought goods to Kaneš, then brought silver back to Aššur. It is possible that Šalim-ahum had either exclusive or primary control over these two persons. As his son, Dān-Aššur's long-term welfare was bolstered by Šalim-ahum's financial well-being, and Dān-Aššur behaved towards his father within a framework of family obligation. ${ }^{37}$ But if Šalim-ahum had exclusive control over Aššur-mālik son of Errāya during this caravan cycle, it was not likely permanent. Ǎšur-mālik seems to have operated as an independent merchant elsewhere and there is more evidence of his tie to Pūšu-kēn than to Šalim-ahum. ${ }^{38}$

36. Erra-idī’s son brought cargo for Šalim-ahum from Aššur early in the caravan cycle that was mostly sold in Lot 2. On the other hand, Aššur-mālik son of Errāya brought silver from Kaneš to Šalim-ahum later in the cycle, which Šalim-ahum acknowledged in the first letter of receipt (6-TC 3 23:12-13). Šalim-ahum did mention both Aššur-mālik without his patronym and the son of Erra-idi in the first letter of receipt (6-TC 3 23:12-13, 17-19). However, Šalim-ahum indicated in an earlier letter that Aššur-mālik son of Errāya arrived with Dān-Aššur at a different time (3-POAT 19:10-11). Moreover, Šalim-ahum consistently referred to the son of Erra-idī by his patronym while Aššur-mālik's name was the essential referent for him.

37. In a more dispersed way, the documentation arising from the archive associated with Dān-Aššur and his brother Ennam-Aššur attests to the fact that the two sons did coordinate activities with their father and certainly on occasion were directed by their father. For a fuller discussion of the family as functioning as a family firm; see references in n. 5 .

38. In KEL 105, Aššur-mālik son of Errāya was recorded as owing 1 mina 41 shekels of silver to a merchant (AKT 149$)$. Aššur-mālik was witness to an agreement between two other merchants ( $A K T 166$ ). He is part of a distribution of textiles recorded in another document where twenty-three other persons also receive or are credited with 1 kirum, while two persons receive or are credited with two kirätum (CCT 5 42a:22-23: 1 ki-ra-am A-šur-ma-lik DUMU Er-ra-a). There is a receipt recording Püšu-kēn paying the kärum for the transport tariff on 4 talents tin (1 $1 \frac{1}{2}$ minas of silver), which apparently Aššur-mālik brought, but there is interest attached, so this is a loan of some kind. Aššur-mālik also 
While the evidence is not conclusive, it seems that several of the other transporters also had more direct connections to Pūšu-kēn than Šalim-ahum. The record on the activities of Aššur-mālik son of Luzina show him coordinating activity with Šalim-ahum and Pūšu-kēn, but also pursuing independent activity. ${ }^{39}$ Aššur-muttabbil son of Šù-Anum is attested owing silver to someone in Pūšu-kēn's circle. ${ }^{40}$ Likewise, Ennam-Aššur son of Šū-Aššur shows up in the same circle as Pūšu-kēn. ${ }^{41}$ Amurrum-bāni son of Puzur-Ištar and Nūr-Ištar son of Idī-Ištar are otherwise unknown; the rest of the transporters do not have patronyms in these documents, and therefore cannot be confidently tracked for this study. To some extent, if he was to respond to developing conditions at either end of the caravan route, Šalim-ahum could not have relied on a small group of transporters. Clearly he could have contracted with transporters through an agent. ${ }^{42}$ But he also seems to have drawn on some transporters on a regular basis, such as Aššur-mālik son of Erraya, Aššur-mālik son of Luzina, Aššur-muttabbil son of Šū-Anum, and Ennam-Aššur son of Šū-Aššur, all of who reappear elsewhere in the business activities of Pūšu-kēn. Some of these transporters may have spent their entire lives as transporters in the trade, but if so, they worked at transporting for a range of different people.

Can we determine differences in the ways in which Šalim-ahum related to the various transporters in the caravan cycle based on lexical grounds? Nür-Ištar was paid the wages (igrū) of a sāridum ("packer"), as mentioned by Šalim-ahum in the bill of lading (1-CCT 2 4b/5a:10), ${ }^{43}$ whereas three of the drivers, Aššur-muttabbil, Ah-šalim, and Amurrum-bāni, were paid with working capital (bẻulätum), which they were to pay back a few months after they reached Kaneš (6-TC 3 23:35-42). Unfortunately, the difference between description (šăridum vs. kașsārum) on the one hand and mode of payment (igrū vs. be'ulätum) on the other are not clear in the caravan cycle. It has been proposed that a kașārum would have functioned as an important and regular employee for firms, as opposed to a sāridum. ${ }^{44}$ In general, documents refer to "the kașsārum of PN," whereas there are no examples of an equivalent "sāridum of PN." There are no examples of wages being paid to a kașșärum, whereas sāridū were commonly paid wages. Thus it might be worth proposing that kașșārum were usually paid with a be'ulätum, and hence more likely employees. But of the transporters paid by be ulatum in the caravan cycle, only one clearly persists beyond this caravan cycle as a member of Šalim-ahum's or his representatives' circles-Aššur-muttabbil, who continues to

appears as son of Errāya, bringing silver to Ǎ̌šur for Kaneš and then bringing goods back in return, purchased by Pūšu-kēn’s representatives (Yale 13092). Aššur-mālik appears in another document that is a series of notes probably written by a son of Pūšu-kēn (TC 1 18); see A. M. Ulshofer Die altassyrischen Privaturkunden, Freiburger altorientalische Studien Beihefte: Altassyrische Texte und Unterschungen 4 (Stuttgart: Steiner, 1995), 106.

39. On the one hand, Aššur-mālik son of Luzina can be seen in a number of cases with Šalim-ahum or the representatives from the caravan cycle. For example, he appeared as the manager of a caravan that had yielded silver for Šalim-ahum (AKT 3 66:21-23); he appeared as witness to a transaction with an Ilī-ālum (BIN 4 152); and he went up to the palace to act as witness for Püšu-kēn in a matter (WAG 48-1465). On the other hand, he appeared to act on his own when he was to be avoided as Sabasia’s creditor (TC 1 51); had a kașsārum (Nāb-Suen) acting for him (kt c/k 305, courtesy J. G. Dercksen); appeared to owe some money to Šü-bēlum (kt n/k 137, courtesy S. Bayram); appeared as managing a caravan again (94/k 414 and 94/k 545, courtesy G. Barjamovic); appeared as a week-eponym official in KEL 104 (CCT 1 6c, kt c/k 1529, courtesy J. G. Dercksen, kt n/k 1839, courtesy V. Donbaz, kt 87/k 155, courtesy K. Hecker). Other references evidence activity but not necessarily independent activity. Aššr-mālik was involved in the transaction of 65 shekels of gold in KEL 111 (AnOr 6 22, no date); was given gold and silver to make purchases in the city of Ǎšur (TTC 3); received a letter with a Šalim-Aššur (kt 94/k 1136, courtesy M. T. Larsen); received some silver in return for wool (kt 94/k 1237, courtesy M. T. Larsen); and was involved in a transaction in KEL 103 (kt 94/k 750, courtesy M. T. Larsen).

40. Aššur-muttabbil was listed as owing 6 minas of silver in a list of debts in which Pūšu-kēn also appeared several times as a witness to transactions (ICK 1 187).

41. Ennam-Aššur was to pay a shekel of gold in the wake of Püšu-kēn's wife's death (TC 130$)$. Elsewhere, he appeared as a witness in a legal proceeding with unrelated persons (k/t 87k 171, courtesy K. Hecker).

42. Already well discussed in Larsen, Old Assyrian Caravan Procedures, 173-78.

43. In addition to wages for sāridum, wages are also mentioned in conjunction with a range of other things and personnel, which reflect

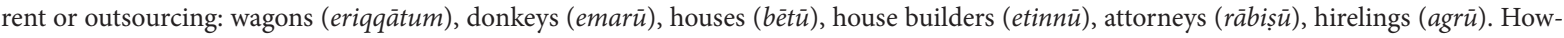
ever wages were also given to individuals who may or may not be classified as employees: messengers (šiprū ), "young men" (șuhārū ), for those carrying "packs" (bilātum) and for those transporting goods, but described neither as a sāridum or kașșārum (radäum).

44. Barjamovic, Historical Geography, 15-16. 
show up in Pūšu-kēn’s circle (not Šalim-ahum's). As a result, it might be premature to map kașsārum and sāridum as employed versus contracted labor. ${ }^{45}$

Šalim-ahum's transporters played an important role in his caravan cycle. However, beyond Šalim-ahum's own son, whose travels Šalim-ahum directed through his letters to his representatives, it is difficult to associate any other transporter directly to Šalim-ahum, especially as an employee whose travels Šalim-ahum directed. Lexical descriptions of roles do not offer much help in describing Šalim-ahum's relation to the transporters as well, though social dynamics may have some effect on whom Šalim-ahum paid with a be'ulātum and whom he paid differently. The difficulty in mapping degrees of stability onto Šalim-ahum's social relationships with his transporters echoes a similar problem of describing his relationship to those who bought his goods.

\section{Šalim-ahum's Buyers and Our Purchase on Language}

Šalim-ahum depended on a second group of people to make his profit: those who purchased his goods. In this article I have described the transaction between this group and Šalim-ahum as a credit sale. Some descriptions of the Old Assyrian family firm would likely identify these transactions with other instances of giving commission goods to travelling or comission agent. Šalim-ahum's representatives would have drawn up a bond (the debt note) with the commission agent that stipulated when he would return a set amount of the proceeds, keeping further proceeds as his profit. ${ }^{46}$ Such descriptions, where both the English "commission" and "agent" imply that the goods entrusted were still owned by the original merchant until payment was received, have been at least indirectly supported by understanding phrases like, "my merchant" or "our PN" to imply durable relationships between parties involved in the transaction, even an employer-employee relationship. ${ }^{47}$ However, a further look at the documentary topography of this caravan cycle suggests that Šalim-ahum treated the transaction as a credit sale. Šalim-ahum's inconsistent use of possessive markers to refer to the buyers suggests that such markers do not provide, in and of themselves, evidence of durable relationships between individuals. Šalim-ahum's discussion, or lack of discussion, of his buyers' identities implies there was a certain social distance between the two parties. Such distance is confirmed by a reconsideration of the structure of the caravan cycle.

In the first place, Šalim-ahum's use of possessives with "his" buyers suggests that our purchase on the language of relationships is relatively insecure. Šalim-ahum occasionally referred to a buyer or buyers as "my merchant(s)" in the epistolary conversation. In one letter, Šalim-ahum wrote, "The term of $m y$ merchant to whom you extended credit in Kaneš is full. Take care to make my merchant pay the silver ... the terms of the merchants, those which are still running, of all of my merchants-their terms are full" (4-TC 1 14:4-8, 19-22). But when the caravan cycle began, Šalim-ahum made no effort to designate specific persons who might buy the goods, writing to his representatives, "Your merchants must be reliable" (1-CCT 2 4b-5a, see also CCT 5 5a:13-21). ${ }^{48}$ After the buyers transacted

45. Note a number of references that need to be worked out in relation to this problem. For example, a șuhärum could also receive a béulätum (CTMMA 1 75:22). In another document, Idī-Aššur takes 1¹/2 minas of silver, described as the be ulātum of his son, but then takes responsibility to fulfill the "hire" (igrū) in the same document. The reference to hire may point to further opportunities to use his son's labor outside of the current arrangement (KT Hahn 22). In another document (ICK 1 83), one merchant goes into a relationship seemingly constrained by debt in which he must make two round trips between Anatolia and Aššur, and he cannot hire others to accomplish the tasks for him.

46. This arrangement was described already in Larsen, Old Assyrian Caravan Procedures, 28, 49-51. Further descriptions, some of which hold the potential for credit sales like the present to be understood in the same way include Veenhof, "Silver and Credit," 208-9; K. R. Veenhof, "Prices and Trade: The Old Assyrian Evidence," AoF 15 (1988) 51-52, and K. R. Veenhof, “Modern Features' in Old Assyrian Trade," JESHO 40 (1997) 347-48.

47. See most recently Barjamovic, Historical Geography, 15, but the practice is much wider. For example, Larsen, Old Assyrian Caravan Procedures, 41 and 150.

48. On other occasions, Šalim-ahum did designate who was to buy his goods in Kaneš. For example, Šalim-ahum clearly designated Ilabrat-bāni to purchase a specific shipment, though in those circumstances Šalim-ahum was forcing Ilabrat-bāni to buy the goods as pennance for earlier problems (TC 126 ; POAT 7; TC 3 20; CCT 2 3). 
business with his representatives, Šalim-ahum's use of possessive markers for "his" buyers suggests the silver they owed him was much more important than any social relationship they may have shared. Šalim-ahum's language never projected a close relationship between both "his" buyers and his assets, for example, "Have my merchants sold my goods?" His focus rather lay in consummating his relationship with his silver, writing of the buyer or buyers, "Make him/them pay" (3-POAT 19:26; 4-TC 1 14:8; 6-TC 3 23:42; 8-BIN 4 26:36, 47). In this caravan cycle, when Šalim-ahum used possessives in referring to merchants who owed him money, he was identifying the ownership of his claims on silver rather than his relationship to the buyers. As a result, the same passage above could be translated differently by directing the reference of the possessive to Šalim-ahum's assets, for example, "The term of the merchant to whom you extended $m y$ credit in Kaneš is full. Take care to make the merchant pay my silver ... the terms of the merchants, those which are still running, of all (those) merchants (who have) my (silver) - their terms are full."

Šalim-ahum's ambiguous relationship to the buyers is reinforced by the interpersonal topography of the epistolary conversation, where the buyers occupy a position more distant from Šalim-ahum than either transporters or representatives. The personal identities of the buyers of the four lots is the most elusive social information in the cycle. Though there were many opportunities to mention their names, Šalim-ahum or his representatives only referred to one buyer by name: Lulu son of Zukuhum, who bought Lot 2 (8-BIN 4 26:8-9). The general disinterest in the buyers' names during the caravan cycle stands in stark contrast to the attention paid both to Šalim-ahum's assets and the transporters who brought them to Kaneš.

Šalim-ahum's assets took three forms through the various phases of the caravan cycle, first as goods transported to Anatolia and sold, then as claims on merchants for silver, then as silver collected and sent back to him. In American accounting language this would correspond to inventory, receivables, then cash. Yet Šalim-ahum distinguished his assets by associating them with the original transporters, even when his assets had been transformed into claims and then silver. Šalim-ahum referred to the claims on silver as "from the goods from the transport of" (ina/ša luqūtim ša šêp) or more simply "from the cargo of" (ša šêp) the transporters. ${ }^{49}$ This did not mean that the drivers purchased the goods upon arrival in Kaneš, as demonstrated by the case of Lulu. And Šalim-ahum consistently described the debts owed by transporters, such as their be'ulätum, simply as ša $\mathrm{PN}$, rather than with the ša šēp PN formula (6-TC 3 23:35-42).

While Šalim-ahum's tendency to refer to his assets consistently in relation to the original drivers facilitates tracking his assets through the three phases, it also suggests something about Šalim-ahum's conception of the caravan cycle and the nature of his assets. Šalim-ahum's conception of the caravan cycle was configured by the first phase, implying a perceived continuity of existence for the caravan cycle as a definite iteration of business. By tracking his assets with reference to the first phase through the second, rather than associating the assets with the persons who held them, Šalim-ahum conveyed a consistent disinterest in persons beyond his representatives and transporters. But Šalim-ahum's mode of referring to his claims also suggests a level of anxiety that came with transformation of his assets from tangible goods to a less tangible claim. Šalim-ahum was in no way uncomfortable with the idea of credit—he no doubt constantly extended credit to merchants in selling his goods-but by continuing to refer to his assets in their previous concrete state, Šalim-ahum reiterated the loss of that state.

Some basic aspects of the caravan cycle and the typical documents employed to forward the process support characterizing these transactions as credit sales. Typically, in the transport phase of the caravan cycle, the owner signaled his retention of ownership by "laying his hand" on the merchandise, noted in the transport contracts. ${ }^{50}$ The transporters later turned over the goods to the representatives when arriving in Kaneš. There, when Šalim-

49. All of the lots in the caravan cycle are described in this manner: Lot 1 (6-TC 3 23:9-10; 8-BIN 4 26:3-4); Lot 2 (6-TC 3 23:17-19); Lot 3 (8-BIN 4 26:45-46); and Lot 4 (6-TC 3 23:5-8, 8-BIN 4 26:41-42). The phrase ša šêp PN is parallel to the less frequently attested phrase ša luqūtim ša šêp PN (TC 1 106:6-8), also reconstructed in 6-TC 3 23:15-19. See Larsen, Old Assyrian Caravan Procedures, 169-70; Ulshofer, Privaturkunden, 263.

50. For laying hands on goods (qätam šakānum), see Larsen, Old Assyrian Caravan Procedures, 28-32. 
ahum's goods were not sold all at one time, he urged his representatives to sell for a cheaper price on the market (3-POAT 19). The representatives' report on the varying prices for which the different lots were sold reflected negotiated prices (2-Prag I 426). Šalim-ahum's representatives sold his goods in exchange for a claim on silver, the typical debt note serving as proof of ownership of the intangible asset. No "laying the hand" procedure seems to have occurred at this point. By their very form, the debt notes that pervade the Old Assyrian trade listed only the silver owed, attesting to the irreversible nature of the transaction. After the sales, Šalim-ahum only carried credit risk-he no longer carried any risk as to the valuation or condition of the goods. ${ }^{51}$ Thus the buyers served as an important point at which both the nature of Šalim-ahum's assets and risks were transformed.

Šalim-ahum benefitted when he sold to people who were reliable but did not share a social or financial connection with him close enough to request leniency when it came time to collect. Šalim-ahum's relative disinterest in the identity of "his" buyers, combined with the way he varied in claiming relationship to them, cautions against interpreting some linguistic tokens as direct indicators of organizational or durable relationships. Šalim-ahum's relative indifference to the identity of his buyers suggests that in this caravan cycle he was buying wholesale on the market in Aššur and selling (on credit) wholesale on the market at Kaneš. At least in this caravan cycle, the buyers did not comprise part of Šalim-ahum's durable commercial network or his employees. However, his mode of transacting business with them, on the market, likely conditioned similar arrangements he would make with persons within his social or commercial network.

\section{Šalim-ahum's Representatives and Šalim-ahum's Interests}

Perhaps the most important group for Šalim-ahum consisted of representatives in Anatolia who coordinated the transition from shipments to sales, collected his claims, and sent his silver off to him in Aššur. The epistolary conversation in this caravan cycle was conducted with this group. Yet a close reading of the epistolary conversation sorts them not as Šalim-ahum's employees but as independent associates. Šalim-ahum drew on a small but flexible pool of merchants whose movements he did not directly control. Moreover, Šalim-ahum's interaction with his representatives suggests a tension between the two parties. While he cultivated personal relationships with these men, he also maintained subtle financial distance from them. Šalim-ahum and his representatives kept separate balance sheets, a fact that Šalim-ahum, either wittingly or unwittingly, exploited in small ways with loose language that had a soft effect of potentially displacing small amounts of risk onto his representatives. Such behavior suggests that Šalim-ahum's representatives were an important part of his commercial network, but not, strictly speaking, part of Šalim-ahum's firm.

Like transporters, Šalim-ahum seems to have drawn on a small but fluid group of representatives rather than a cadre of stationary employees. Šalim-ahum's representatives had their own affairs and movements, so Šalim-ahum needed to have multiple representatives to accommodate situations when some of his representatives turned their attention elsewhere. Three different persons represented Šalim-ahum in Kaneš during the caravan cycle: Pūšu-kēn, Là-qēpum, and Ilì-ālum. In addition, Hinnaya seemed to represent Šalim-ahum in Durhumit (4-TC 1 14:27-30). The recovered documents reviewed here were most likely stored in Pūšu-kēn's archive. Pūšu-kēn and Lā-qēpum consistently appear as addressor or addressee in all the letters where the pertinent section is preserved, whereas Ilī-ālum entered and exited duties of representation for Šalim-ahum without Šalim-ahum's direction. As reviewed in the reconstruction, Ilì-ālum did not represent Šalim-ahum until after the goods made their way to Anatolia, and Šalim-ahum learned of it ex post facto. Later, Ilī-ālum returned to Aššur, leaving the business to be handled by Pūšu-kēn and Là-qēpum (8-BIN 4 26:28-29). The documentation also suggests that neither Lā-qēpum nor Pūšu-

51. Old Assyrian merchants did face the risk of goods losing value independent of market fluctuations, particularly textiles. For problems with moths in the Assyrian textile trade, see C. Michel, "Les Mites d'Assyrie: Moths in the Assyrian Texts of the Second Millennium B.C.," JAOS 118 (1998) 325-31. 
kēn were consistently stationed in Kaneš to continuously oversee Šalim-ahum's affairs. Šalim-ahum mentioned claims arising from goods brought to Anatolia from Aššur by both men in the recent past (4-TC 1 14:16-18; 6-TC 3 23:15-17; 8-BIN 4 26:6-7).

A sense of social and commercial distance between Šalim-ahum and his representatives also comes through in the texture of the epistolary conversation. Both Šalim-ahum and his representatives describe or discuss assets or persons as the exclusive domain of Šalim-ahum, rather than as shared assets. For example, Šalim-ahum did not say how much silver he paid for the "extremely fine" textiles brought by Nür-Ištar (1-CCT 2 4b/5a). Nor did he tell his representatives how much silver he spent on his goods in other notifying messages he sent in conjunction with other shipments (TC 321 ; CCT $24 a$ ). These facts were information he did not feel obligated to share, because each merchant carried a distinct balance sheet of profits and losses. Likewise, when the representatives recorded that they received silver from "Šalim-ahum's merchant," (5-VS 26 130:6'-8'), who should be identified as the buyer of Lot 1, they project the same social distance to the buyer and to Šalim-ahum as observed between Šalim-ahum and "his" buyers.

Šalim-ahum also treated the act of accounting between himself and his representatives as one between separate parties, though outside of a legal sphere. Šalim-ahum's communication with his representatives in this context highlights at once the close relationship between his representatives and their own independent liabilities. As mentioned earlier, Šalim-ahum had a tendency to be less accurate when making accounts with his representatives than he was in legal documents. Šalim-ahum's problem with precision was not likely due to problems with record keeping or to lack of records. If he was anything like Pūšu-kēn, whose archive supplied these documents, then he was keeping many documents associated with the caravan cycle, both copies of letters he sent away and those he had received. Moreover, Šalim-ahum showed that he knew when claims matured, reminding the representatives to collect the claims in a timely manner several times during the caravan cycle. Furthermore, he also clarified the amounts of assets on occasion, as with the first time he mentioned the debts in Durhumit in the epistolary conversation (3-POAT 19:21-27). In the two intermediate accounts (6-TC 3 23; 8-BIN 4 26) Šalim-ahum was both more formal and more precise (made smaller errors) than in some other letters. But the small discrepancies in two of his figures in the intermediate accounts had their effect on the intermediate balances, which Šalim-ahum claimed between himself and his representatives. Šalim-ahum's errors totaled only $3 \frac{11}{2}$ shekels of silver, but they might suggest something subtle because they were both in his favor. If his representatives were obligated to accurately report Šalim-ahum's assets, Šalim-ahum did not feel obliged to the same degree.

If this subtle pattern of inflating figures can be taken for intentional communication, then Šalim-ahum could be seen to have displaced small amounts of risk onto Pūšu-kēn and the other representatives by attempting to obligate them to send more silver than was actually due. Šalim-ahum's minor errors in his favor in the intermediate accounts might not comprise an outright attempt by Šalim-ahum to cheat his representatives. Pūšu-kēn or the other representatives would not likely have been fooled by the small errors, nor considered them serious. However, seemingly small amounts of goods or silver could mean a great deal to Šalim-ahum. When another merchant, Ilabrat-bāni, took $61 / 3$ minas of tin (worth about 1 mina silver) from Šalim-ahum's goods while transporting them to Kaneš, Šalim-ahum reacted very angrily (see BIN 4 61; TC 2 3; POAT 7). Šalim-ahum's tendency toward accounting errors suggests that Šalim-ahum might have felt he could occasionally gain something from them; but this may be reading too far into the variances.

Still, there are reasons to take Šalim-ahum's imprecision seriously, even if he may have not. In legal contexts, when a document was created, all parties or their representatives were present to ensure its accuracy. By contrast, Šalim-ahum and his representatives were, by design, in different places. Though the intermediate accounts lacked witnesses of both parties' acceptance of the document and thus legal force, Šalim-ahum's list of silver still to be collected was a statement of responsibility for his representatives. Šalim-ahum's descriptions were reasonably accurate, and he did not risk the same consequences of misstating assets in a legal statement. And yet, if Šalim-ahum frequently inflated his claims in intermediate accounts with his representatives, some tension between he and his representatives was likely to arise. After all, the representatives were keeping copies of the letters they sent (2-Prag I 426; 7-CCT 5 50b) and their own documentation (5-VS 26 130). 


\section{Conclusions}

Šalim-ahum's caravan cycle constitutes the most well-documented example of a common sequence of activity in the Old Assyrian trade. The manner in which Šalim-ahum pursued his caravan cycle does not comprise the only approach employed by merchants participating in the Old Assyrian trade. Nor does it represent a complete characterization of Šalim-ahum's business. But the reconstruction afforded by the documentation provides an opportunity to sift between language and practice and permits a consideration of the social topographies possible in accomplishing the trade.

While selecting Šalim-ahum's caravan cycle means looking narrowly at a single process, it well manifests a productive dialectic between language and practice in describing the Old Assyrian trade. Evaluating the reliability of reconstructions of merchant activity has in part hinged on agreement of descriptions of assets and other aspects across documents. However Šalim-ahum's occasionally loose descriptions of his assets obscure some of the simplest material elements of the caravan cycle, suggesting that in some contexts, such as when assets are merely being identified for general purposes, there is reason to expect less precision than in legal documents. Šalim-ahum's epistolary conversation with his representatives during this caravan cycle also suggests that linguistic markers do not in and of themselves portray social facts of the trade. Šalim-ahum's tendency to refer to buyers as "his" merchants seems a misleading indicator of any social closeness between them. The formality of the intermediate accounts ordered a portion of the epistolary conversation between Šalim-ahum and his representatives. Yet within the context of that formality, Šalim-ahum still seemed to manifest evidence of competing interests with his representatives. Recognizing variations in detail as part of a conversational context, or perhaps a manifestation of conflicting interests, suggests wrinkles in validating reconstructions of discrete events drawn from a mass of seemingly homogeneous commercial activity.

Šalim-ahum's caravan cycle and its epistolary conversation also project a social topography that reveals Šalimahum's commercial network in this cycle as distinct from that associated with larger family firms. Other merchants in the Old Assyrian trade, such as Imdi-ilum, operated within family firms in which extended family formed the core of a large commercial network of cooperating merchants..$^{52}$ In the case of Šalim-ahum's caravan cycle, we cannot finally verify that most of his transporters and even his representatives may have been related to him in some way to him. No model of the family firm demands that everyone Šalim-ahum worked with was related to him. But in Šalim-ahum's caravan cycle, attempting to sort between the participants who had a durable commercial relation to Šalim-ahum or shared in his short-term commercial interests-persons we might associate as employees or members of his firm-is like peeling away successive layers of an onion until effectively only Šalim-ahum and his son remain. Šalim-ahum made use of a seemingly flexible supply of transporters, buyers and, to a lesser extent, representatives, to pursue this caravan cycle. And though Šalim-ahum dictated the movements of his son DānAššur, his son was flanked by a larger group of transporters who cannot be confidently characterized as Šalimahum's employees. Likewise, Šalim-ahum's buyers met Šalim-ahum's representatives in the context of the market rather than in the context of a firm. Šalim-ahum's representatives, including Pūšu-kēn, Lā-qēpum, and Ilì-ālum, and likely also Hinnaya, appeared as coordinating associates but not exclusive employees, entering and exiting the caravan cycle without Šalim-ahum's direction, and perhaps suffering the manipulations of Šalim-ahum's intermediate accountings.

Šalim-ahum's operational arrangements with other merchants in this caravan cycle might be understood as an effective approach for a wealthy person in a particular phase of his life. It is possible to see Šalim-ahum as someone who had no need to build up a significant interpersonal network in Anatolia. With his wealth and potential to invest, Šalim-ahum could easily attract merchants to represent him in Anatolia when they were available. At the

52. M. Ichisar, Les Archives cappadociennes du marchand Imdilum (Paris: A.D.P.F., 1981), and M. T. Larsen, "Your Money or Your Life: Portrait of an Old Assyrian Businessman," in Societies and Languages of the Ancient Near East: Studies in Honour of I.M. Diakonoff(Warminster: Aris \& Phillips, 1982), 214-45. 
same time, Šalim-ahum may have required representatives like Pūšu-kēn and the others more intensively when his sons were younger. If this caravan cycle took place before Dān-Aššur or Ennam-Aššur (one of Šalim-ahum's older sons who was also active in the trade) had established significant commercial networks of their own, then their value to Šalim-ahum as representatives in Anatolia would have been minimal. Without a significant network of contacts in Anatolia, Šalim-ahum was far more aware of the identities of his transporters than of those who bought his goods in Kaneš. It seems that one productive strategy was for Šalim-ahum to buy and sell his goods wholesale and avoid too many entanglements in the further operations of the trade on the Anatolian plateau. If so, Salimahum's sale to unknown buyers during the caravan cycle suggests that sometimes social distance among Assyrians may have been as important to the function of the trade as family relations. 